\title{
Forced Marriage and Birth Outcomes
}

$\begin{array}{ccc}\text { Charles } & \text { Bakhrom } & \text { Susan } \\ \text { M. Becker } & \text { Mirkasimov } & \text { Steiner } \\ \text { Duke } & \text { University of } & \text { Leibniz } \\ \text { University } & \text { Tashkent } & \begin{array}{c}\text { Universität } \\ \text { Hannover/ } \\ \end{array} \\ & & \text { IZA }\end{array}$

April 6, 2016

ERID Working Paper Number 204

This paper can be downloaded without charge from the Social Science Research Network Electronic Paper Collection:

http://ssrn.com/abstract=2730727

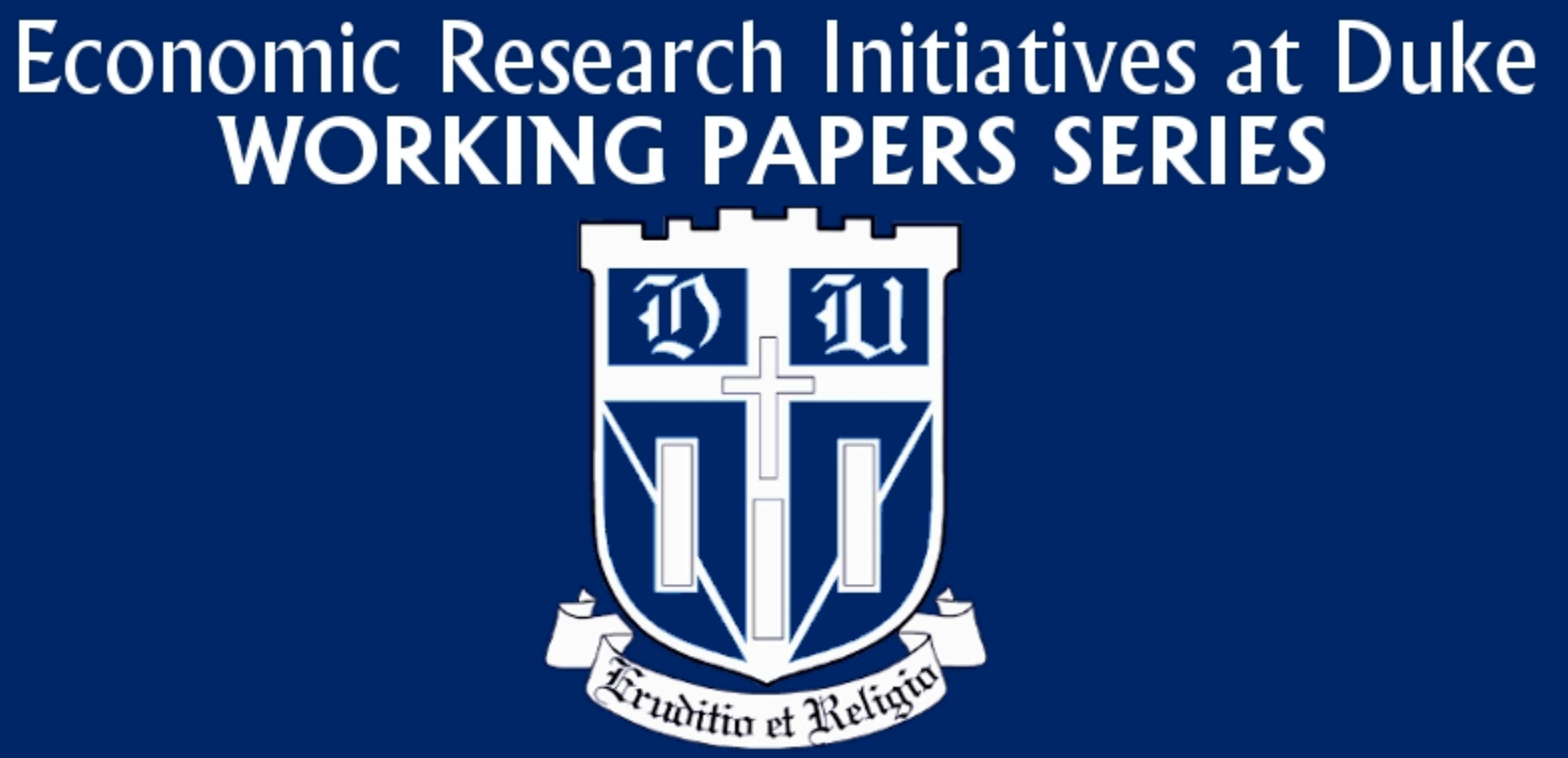




\title{
FORCED MARRIAGE AND BIRTH OUTCOMES
}

\author{
Charles M. Becker ${ }^{\dagger}$, Bakhrom Mirkasimov ${ }^{\dagger+}$ and Susan Steiner ${ }^{\ddagger}$
}

April 2016

\begin{abstract}
:
We study the impact of bride kidnapping, a form of marriage practiced in Central Asia and elsewhere, on infant birth weight. Considerable debate exists as to whether kidnapping is merely ritualized elopement, or whether it involves bride coercion. To the extent that it is non-consensual, we expect adverse consequences from such marriages, working through poor spousal matching quality and subsequent psychosocial stress. Remarkable survey data from rural Kyrgyzstan enable us to explore differential outcomes for kidnapped women. We apply several estimation models, including an IV estimation in which we instrument kidnapping among young women with the district-level prevalence of kidnapping among older women and an OLS regression with district fixed effects. Our findings indicate that children born to kidnapped mothers are of a substantially lower birth weight than children born to mothers who are not kidnapped. We further find less positively assorted mating among spouses in kidnapped marriages than in other types and higher divorce rates among kidnapped women. These findings have important implications for children's long-term development; they also discredit the ritualized-kidnapping-as-elopement view.
\end{abstract}

Keywords: Forced Marriage, Bride Kidnapping, Birth weight, Stress, Kyrgyzstan JEL classification: I12, J12

Acknowledgements: We thank Giovanna d'Adda, Victor Agadjanian, Kathryn Anderson, Bezawit Beyene Chichaibelu, Christopher Edling, Damir Esenaliev, Bernd Fitzenberger, Urakorn Fuderich, Adrian Garcia-Mosqueira, Robert Garlick, Priscilla Hermida, Aliya Ibragimova, Joshua Jacobs, Olga Kozlova, Bohdan Krawchenko, Natalia Kyui, Sabine Liebenehm, Nathan Light, Mieke Meurs, Luciano Mauro, Huon Morton, Akylai Muktarbek kyzy, Dan Oldman, Kani Omurzakova, Sultan Omurzakov, Klara Sabirianova Peter, Daniel Rees, Daniel Schnitzlein, Cathy Starkweather, Artem Streltsov, Sebastian Vollmer and Marlene Waske for helpful comments. We also received crucial feedback from participants of workshops, seminars and conferences at the American University of Central Asia, El Colegio de Mexico, Humboldt University of Berlin, Leibniz Universität Hannover, University of Hamburg, and the University of Göttingen. We are grateful to the National Statistical Committee of the Kyrgyz Republic and the German Research Centre for Geosciences in Potsdam for providing us with different types of data. All errors, omissions, and faulty interpretations remain our own.

\footnotetext{
${ }^{\dagger}$ Duke University

"H Humboldt University of Berlin, University of Central Asia (UCA) and Westminster International University in Tashkent (WIUT)

${ }^{\ddagger}$ Leibniz Universität Hannover and IZA
} 


\section{INTRODUCTION}

Economists have addressed many questions about love marriages in which both spouses of a couple select one another after a period of courtship and arranged marriages in which other parties are primarily responsible for the spousal search (Fafchamps and Quisumbing, 2008; Weiss, 1997). In contrast, forced marriages have not received much attention. We argue in this paper that forced marriages are substantially different in nature than love and arranged marriages in terms of spousal search, spousal matching, and the resulting quality of the marriage. We hypothesize that the stress level of women who were forced into marriage is higher than that of women who had a choice over their spouse. Given that stress was repeatedly shown to be an important determinant of birth outcomes (Bozzoli and Quintana-Domeque, 2014; Camacho, 2008; Foureaux Koppensteiner and Manacorda, 2016; Mansour and Rees, 2012; Torche, 2011), we expect the birth outcomes of women in forced marriages to be worse than those of women in other types of marriage.

We investigate the impact of forced marriage on birth weight. This impact is of high policy relevance. If we find a negative impact, forced marriage does not only have adverse consequences for the women involved but also for their children: Birth weight is a primary marker of infant health and affects long-run outcomes such as adult height, completed education, and earnings (Behrman and Rosenzweig, 2004; Black et al., 2007).

The forced marriages that we study are marriages resulting from bride kidnapping. We focus on Kyrgyzstan - a small country with a population of 5.8 million located in Central Asia - but this is not the only country where bride kidnapping is practiced. According to ethnographic reports, various forms of kidnapping (also referred to as abduction or capture) existed in societies across Europe, Asia, Africa, Australia and the Americas in the past (Ayres, 1974; Barnes, 1999; Bates, 1974; McLaren, 2001; Stross, 1974). In many places, kidnapping no longer seems to be a common phenomenon, but evidence shows that it is still practiced in such countries as Armenia, Ethiopia, Kazakhstan, and South Africa (Dito, 2015; Edling, 2012; Nkosi and Buthelezi, 2013; Rice, 2014; Werner, 2009).

Kyrgyzstan has a reputation for being reformist, pluralistic, and placing fewer constraints on women than some of its former Soviet neighbors and countries further south such as Afghanistan, Iran, or Pakistan. Women hold high positions in society and politics; recently, a woman, Roza Otunbayeva, served as President. At the same time, this apparent outpost of liberal values is also a society in which a significant percentage of women - an estimated 16-24 percent (Nedoluzhko and Agadjanian, 2015; Za Reformy i Rezul'tat, 2015) - are married following kidnapping.

The extent of force involved in the kidnapping appears to vary widely (Amsler and Kleinbach, 1999; Kleinbach et al., 2005). One extreme is fully non-consensual abduction in which the bride is kidnapped by the groom through physical force. Another extreme is elopement or staged abduction, where the groom and the bride agree on the kidnapping beforehand - for example, when their parents do not approve of a marriage. The stress level for the women in the resulting marriage is expected to differ accordingly, with higher stress after non-consensual abduction and lower stress after elopement. The Life in Kyrgyzstan survey (Brück et al., 2014) data used in our empirical analysis do not distinguish between different degrees of force involved in kidnapping. Our estimation results may therefore underestimate the effect of forced marriage on birth weight. However, our primary interest is to determine whether there is any negative impact of kidnapped marriages on birth weight; we place less importance on the exact magnitude of this impact. 
We focus on rural Kyrgyzstan and compare the birth weight for the children of women who were kidnapped to those of women who had arranged marriages. We exclude women in love marriages in our empirical analysis. Love marriages seem to be systematically different from arranged and kidnapped marriages and to be imprecisely measured in our survey data. We employ two estimation approaches. The first is a simple OLS regression with district fixed effects in which we compare the birth weight in kidnapped and arranged marriages within the same district to each other. The second is an instrumental variable estimation to avoid any potential omitted variable bias. Our instrument is the percentage of marriages within a district that resulted from kidnapping. We calculate this district-level share from women aged 44 and above and use it as an instrument for women aged 43 and below. We take great care to ensure that this district-level share is exogenous and does not capture geographic variation in other variables, such as poverty rates or the availability of health care, which might also affect infant's birth weight.

We find that birth outcomes are worse among children born to kidnapped mothers compared with children born to mothers in arranged marriages. The loss in birth weight is consistently negative across different estimation models and robustness tests. Children of kidnapped mothers are about 100-200 grams (3 to 6 percent) lighter than other children; this weight difference is sizable and comparable to losses generated by other traumatic events. We interpret this result as a sign that kidnapped marriage is a form of marriage that, on average, lacks the consent of the women and is based on some degree of force, possibly including physical force. This force, in turn, leads to psycho-social stress among the women who then give birth to smaller children. We acknowledge that lower birth weight may also be triggered by more strenuous physical work, poorer nutrition, less prenatal care, or shorter birth intervals among kidnapped women compared with women in arranged marriages. We cannot fully dismiss these channels but we provide descriptive evidence that none of these other channels is as plausible as the stress channel.

\section{BACKGROUND: KIDNAPPING OF BRIDES IN KYRGYZSTAN}

Bride kidnapping, called ala kachuu in Kyrgyz (literally: "to take and run away"), is the act of abducting a woman to marry her. In Kyrgyzstan, kidnapping is illegal, with a maximum prison sentence of three to seven years, or up to ten years if the kidnapped bride is below the minimum legal age for marriage of 17 years. ${ }^{1}$ However, few people report cases of kidnapping to the authorities; prosecutions are very rare. No numbers may be more telling than the commentary Kyrgysstan: courts tackle sheep theft, ignore bride kidnapping on October 2, 2012 on the English-language news channel Eurasianet (http://www.eurasianet.org/node/65989): 666 cases of livestock theft brought criminal charges during the period January-August 2012, as against only 10 cases of bride kidnapping. In general, law enforcement and legal protection for women are rather weak (Human Rights Watch, 2006).

In Kyrgyzstan, the practice of kidnapping is essentially limited to ethnic Kyrgyz, who account for 71 percent of the population (NSC, 2009). Other ethnic groups do not engage in kidnapping, with very few exceptions, but marry either through love or arranged marriages (Handrahan, 2004).

1 These penalties are determined in a new bride kidnapping bill that came into law in January 2013. Bride kidnapping had been illegal before, and in fact, since the 1920s when the Soviet Union established laws for banning it (Werner, 2009). 
That Kyrgyz (and Kazakhs in southern Kazakhstan) tolerate kidnapping while more conservative Uzbeks and Tajiks do not is one of the puzzles that remain to be explained. Religion does not serve as an explanation, since the vast majority of Kyrgyzstan, including Kyrgyz, Uzbeks, and Tajiks, are Muslims. Werner (2009: 321) states: "bride abduction is not an Islamic practice [...] people in Kazakhstan and Kyrgyzstan do not link bride abduction and religious custom.",2

Ala kachuu usually involves a potential groom and his male friends taking a young woman into a car, and then transporting her to his home. The woman might be kidnapped from her house or another location, such as a school or her workplace. In the groom's home, she is pressured by the groom's female relatives to write a letter of "consent" to her family and put on a marriage scarf. Once she puts the marriage scarf over her hair, she accepts the marriage (Borbieva, 2012). This process could last from a few hours to several days. Eventually, the groom's family goes to visit the bride's parents to "apologize", to hand over their daughter's letter, and, traditionally, to offer sheep and other gifts. Such offers are considered the bride price (kalym). It is in principle possible for the woman to resist the kidnapping. Amsler and Kleinbach (1999) estimate that 17 percent of kidnappings do not result in marriage, either because the woman herself or her family resist. Kleinbach et al. (2005) provide an estimate of only 8 percent.

A few scholars attempted to explain why most kidnapped women stay with their kidnapper and why the women's parents agree to this practice. Werner (2009) argued that the act of kidnapping damages the reputation of the women, and the acceptance of marriage helps to restore that reputation. This is because, after abduction, the women were assumed to no longer be virgins. In addition, they might be perceived as stubborn and belligerent if they resisted the kidnapping. Taken together, kidnapped women were unattractive to other potential suitors. A related explanation was provided by Borbieva (2012) who emphasized the role of marriage as a social institution. She noted that women and men in Kyrgyzstan were expected to marry young and without long courtships for a number of reasons: the lack of social acceptance of premarital sexual activity, the expectation for women to have many children, but most importantly, the function of marriage as transition to full adult status. Families of women with relatively poor perspectives on the marriage market might thus be particularly inclined to give in to kidnapping. Finally, Handrahan (2004) made the point that kidnapping is often used as an act of ethnic definition. A "woman who rejects kidnapping is seen to be rejecting not only a Kyrgyz tradition but also Kyrgyz ethnicity" (Handrahan, 2004: 222). Rejection in turn might create conflict within the community since it implied denunciation of a common practice, especially where kidnapping is very prevalent.

Data on the prevalence of kidnapping and marriages resulting from kidnapping are rare. Nedoluzhko and Agadjanian (2015) conducted a nationally representative survey in 2011/12 among slightly more than 2,000 households. The authors reported that one third of marriages among Kyrgyz were the result of kidnappings; half of these marriages were of a non-consensual nature. The authors pointed out that the risk of kidnapping declined since the collapse of the Soviet Union, particularly within the most recent marriage cohort. According to another survey among all households in one village in 2004, 80 percent of Kyrgyz marriages were the result of kidnapping (Kleinbach et al., 2005). Only 34 percent of the kidnappings took place with the woman's consent, 46 percent of the women were kidnapped through deception and 18 percent were taken by physical

\footnotetext{
${ }^{2}$ The widespread presence of kidnapping in Armenia (Edling, 2012), Ethiopia (Dito, 2015) and parts of South Africa (Nkosi and Buthelezi, 2013; Rice, 2014) and its apparent similarity to the practice in Kyrgyzstan also make it clear that kidnapping is not confined to a particular religion.
} 
force. One fifth of the kidnapped women reported that they had not known their kidnappers. A slightly lower prevalence is reported in a study of roughly 1,600 women for the International Crime Victims Unit Survey conducted by the local NGO Za Reformy $i$ Rezul'tat (2015). This survey, which covers all Kyrgyzstani women without ethnic distinction, finds that 16 percent of married women were abducted for the purpose of marriage. Of these, 34 percent did not agree in advance to their abduction.

There is limited information on the characteristics of the kidnappers and the kidnapped women. Handrahan (2004) conducted a survey among men across Kyrgyzstan. Her most striking result was that there was no relationship between a man's education as well as profession and his likelihood to kidnap. Kleinbach et al. (2005) interviewed the women of one predominantly Kyrgyz village and found that both kidnappers and kidnapped women had reasonable levels of education. Only 10 percent of the men and 12 percent of the women had less than secondary schooling. In contrast, 14 percent of the men and 21 percent of the women had a university degree. Nedoluzhko and Agadjanian (2015) studied the relative risks of marriage resulting from kidnapping among a representative sample of men and women. They showed that being employed did not make kidnapped marriage any more likely than not being employed. People with only basic secondary education were far less likely to be in a kidnapped marriage than people with higher education. People enrolled in education were less likely to be married through kidnapping than people with completed education. Father's occupation, as a proxy of family background, only mattered in the case of forced kidnapping: If the own father worked in agriculture, men and women were more likely to have a kidnapped marriage than if the father had a different occupation.

\section{Conceptual Framework}

\subsection{THE ECONOMICS OF MARRIAGE FORMATION}

Marriage markets are characterized by uncertainty of outcomes and search costs because of scarce information about potential mates (Browning et al., 2014). In most societies, heterosexual, monogamous marriage can be the outcome of (1) an own search process in which a couple identifies one another following search activity; the groom usually proposes to the bride, and the bride accepts; or (2) a delegated search with negotiated activity by third parties on behalf of the bride and groom, who cede some of their selection power. They may do this voluntarily, in recognition of the superior selection ability of the third party, or less enthusiastically in recognition of local custom. In the Kyrgyz setting, kidnapping which is a limited, one-sided search involving unilateral, possibly coercive action by the groom is a third option.

From the groom's perspective, search and courtship costs for a love marriage are high in terms of time and money, and the marital outcome is not certain. The potential bride can choose to select his offer or refuse to marry but continue the search. Both partners compare each other's characteristics and evaluate their potential gains from formation of this union. If the gains to both partners from marriage are greater than their expected gains from continued search for a potential mate, then they marry (Becker, 1973, 1974, 1991). This outcome is the fundamental logic behind the economic analysis of marriage formation. Individual consent is central to love marriages because with individual consent comes individual bargaining power (Edlund and Lagerlöf, 2006). 
The search for a potential spouse in an arranged marriage is not undertaken by the groom directly but by his parents, relatives, or a contracted external party. The process may be longer or shorter than the own-search depending on market conditions, relative bargaining skills of the various parties, and attractiveness of the groom. In arranged marriages, there is substantial variation in the extent of external involvement. Similar to love marriages, both mates generally have a choice, can evaluate their gains from marriage and request continuation of the spousal search if they wish so (Batabyal, 2001, 1999, 1998). A formal model that incorporates preferences for "marrying up" is presented in Banerjee et al. (2013).

The search for a suitable mate in a kidnapped marriage is initiated by the groom, but there is typically non-coerced consent only by the male. ${ }^{3}$ The groom collects limited information about the woman he targets and evaluates his potential gain from marriage to her. The potential bride lacks choice over her potential groom after she is kidnapped. She cannot select from her prospective mate options and signal interest to the one mate who gives her the highest expected gains from marriage. Relative to love and arranged marriages, her expected gains are thus lower in kidnapped marriages. ${ }^{4}$

\subsection{THE MEASURABLE CONSEQUENCES OF BEING KIDNAPPED}

The women in kidnapped marriages have to live with a spouse whom they did not select and with whom they do not necessarily share common interests and attitudes on such important things as female labor force participation or children's upbringing. It is not difficult to imagine that this implies emotional and psychological, possibly even physical, costs to the women. ${ }^{5}$ We hypothesize that their stress levels are higher than those of women in other types of marriage, on average.

Psycho-social stress has been related with poor birth outcomes (Almond and Currie, 2011; Hobel et al., 2008). The medical explanation is that psycho-social stress activates the neuroendocrine stress response, which results in maternal endocrine changes, accelerated fetal maturation and, consequently, pre-term birth and low birth weight. Several authors have estimated the effect of stress on birth weight. Camacho (2008) links random landmine explosions to a woman's birth outcomes based on a census of births in Colombia. She finds a nearly 9-gram decline in birth weight for infants born to women living in a municipality that experienced landmine explosions. The effect is still greater when the explosions occurred during the first trimester of pregnancy.

Torche (2011) examines the effect of the 2005 Tarapaca earthquake in Chile and finds a large impact of exposure: birth weight is reduced by 51 grams on average and the probability of low birth weight, i.e., below 2,500 grams, increases. These effects appear to be driven by an increase in prematurity. Mansour and Rees (2012) assess the effects of armed conflict during the al-Aqsa Intifada on the incidence of low birth weight, using as their stress measure the number of

\footnotetext{
${ }^{3}$ Kidnapping for show - staged elopement - with the prior agreement of both parties is a form of own search marriage. The empirical question is whether virtually all kidnappings are mutually pre-arranged, making them in fact a subset of own search marriages.

${ }^{4}$ In principle, there is also a fourth option facing prospective grooms and brides: abstention from marriage. This option is empirically unimportant in Kyrgyzstan and is an easily dominated option for all but a tiny number of people (Borbieva, 2012).

${ }^{5}$ Even though it is extremely difficult to obtain reliable numbers, a certain proportion of kidnappings seem to involve rape (Za Reformy i Rezul'tat, 2015).
} 
Palestinians killed by the Israeli Defense Force in the mother's district during her first trimester of pregnancy. As they use a small sample, from the Palestinian Demographic and Health Survey, the authors face many of the inferential difficulties that also emerge in our empirical analysis; nonetheless, a clear link between fighting and low birth weight emerges.

Foureaux Koppensteiner and Manacorda (2016) examine the role of neighborhood violence in a set of small municipalities as well as the large and violent city of Fortaleza in Brazil on birth outcomes. They find that increased violence leads to increased prematurity and low birth weight. An additional homicide in the small municipalities results in a 0.6 percentage point (or about 8 percent) higher probability of low birth weight. They conclude that homicides are responsible for about one percent of low birth weight and 3.5 percent of very low birth weight, i.e., below 1,500 grams, in urban Brazil; put differently, an additional 10 homicides result in about 10 low birth weight and 3 very low birth weight births. Finally, Bozzoli and Quintana-Domeque (2014) consider the role of Argentina's economic crisis in the early 2000s on birth weight across mothers with different levels of education. They find that birth weight declined by roughly 30 grams as a result of the crisis; the fluctuation from nadir to normalcy is more on the order of 70 grams. As the Colombian and Chilean datasets, the Argentinean data cover administrative records on millions of births.

Taken together, these studies on the effect of stress on birth weight have several common features, despite using a range of data sources, from small sample surveys to vast administrative vital statistics records. They are all reduced form, so that the precise causal mechanism remains unknown. As reduced form studies, they all rely on natural experiments or exogenous fluctuations in underlying conditions. It is striking that none of them explores other stress impacts, such as on life satisfaction or physical health conditions of women, usually due to the absence of such information in the datasets used. One of our contributions is to demonstrate that the stress experienced by women in kidnapped marriages affects other factors as well, thereby making the stress mechanism more convincing.

We acknowledge that marriage resulting from kidnapping may affect birth weight through other channels than through stress. We investigate the plausibility of these channels in the context of Kyrgyzstan below. In principle, kidnapped women might be obliged to do more strenuous household work during pregnancy. Physical exertion has been associated with low birth weight (Bonzini et al., 2007). Second, kidnapped women might receive poorer nutrition compared with other women. Dramatic reduction in maternal nutrition, such as during famines, induces lower birth weight (Stein and Lumey, 2000); lower birth weight is also the outcome of mild prenatal nutritional deprivation (Almond and Currie, 2011; Almond and Mazumder, 2011). Third, kidnapped women might enjoy less prenatal care. Grossman and Joyce (1990) and Wehby et al. (2009) show that less frequent prenatal visits decrease birth weight significantly. Fourth, kidnapped women might have shorter birth intervals which may lead to lower birth weight due to nutritional depletion (Kramer, 1987). They also may have births at younger ages, but we can and do control for this.

\section{DATA}

Our data are from the Life in Kyrgyzstan (LIK) survey (Brück et al., 2014), which was collected annually between 2010 and 2013. Two of the authors were involved in designing and implementing the survey. The sampling technique was stratified, two-stage random sampling based on the 2009 Population Census with probabilities proportional to population size. The strata were formed by 
Bishkek (capital city), Osh city (the major city in southern Kyrgyzstan), and the rural and urban areas of the seven provinces (oblasts). The data are representative at the national, urban/rural and North/South levels.

We use data from the 2011 LIK wave, which is the wave that provides the most information on marriage and fertility of the respondents. The 2011 wave contains information on 8,066 adults (aged 18 and above) in 2,863 households in 120 urban and rural communities. Female respondents were asked whether they have ever been married. If yes, they were then asked about the evolution of this marriage. The exact wording for this question was: How did this marriage come about? The answer options were: a) love marriage, b) arranged marriage, and c) bride kidnapping. ${ }^{6}$ We are unable to distinguish between different degrees of force involved in the kidnapping.

In the below analysis, we exclude women living in the two major cities of Kyrgyzstan - Bishkek and Osh - for two reasons. First, kidnapping should be much less attractive in settings in which there is a steady arrival of prospective marriage partners, and this appears to be the case empirically (Handrahan, 2000). Second, living conditions differ dramatically: the cities are far wealthier. They are also culturally closer to Europe than to rural Central Asia, and Russian remains the dominant language, especially in Bishkek.

Among Kyrgyz rural women who are or were married, 23.8 percent report that they got married through the process of kidnapping, 53.4 percent report love marriage, and 22.8 percent report arranged marriage. ${ }^{8,9}$ Figure 1 shows the incidence of the different marriage types by year of marriage. We only include the marriage period 1965-2010 in this figure because we have too few (less than ten) observations for the years before 1965 and for the year 2011 in our dataset. The share of love marriages clearly increased over this period, and the share of both kidnapped and arranged

\footnotetext{
${ }^{6}$ It may seem awkward to ask such a question in a survey since it refers to seemingly sensitive information. When drafting the questionnaire, we were concerned about this and almost dropped the idea of including the question. However, after consulting with an anthropologist who worked on the marriage market in Kyrgyzstan (Nathan Light), he assured us that Kyrgyz people do not regard this information to be sensitive, and they talk a lot about kidnappings. He encouraged us to ask the question as bluntly as we did. We know from conversations with Victor Agadjanian that questions about kidnapping were not problematic in their study (Nedoluzhko and Agadjanian, 2015). We also spoke with many Kyrgyz friends, colleagues, and professionals and affirmed that kidnapping is regarded as a fact of life that one can talk about openly. We collected many stories of kidnappings.

${ }^{7}$ We believe that to some degree kidnapping is an affront to the bride's family. No one can kidnap the local akim's (mayor, or most senior government official) daughter; no one should kidnap a woman from a markedly higher social stratum. In such cases, retaliation - legal or extra-legal from the woman's family would be severe. These constraints make it less attractive to kidnap a woman whose background is uncertain to the prospective groom, which reduces the incentives to kidnap in populous settings where many people do not know one another.

${ }^{8}$ Among the older generation of women (as defined below), the respective shares are 25.8 percent, 45.7 percent and 28.5 percent; among the younger generation, the shares are 21.8 percent, 61.2 percent and 17.0 percent, respectively.

9 We only consider information about the first marriage. The women in our sample are not necessarily married to their first husbands at the time of data collection. A small share, namely 2.6 percent of the women, got married a second time; 6 percent are divorced, and 2 percent are widowed. We ignore the type of second marriage as well as children born during second marriages.
} 
marriages decreased, especially in the most recent years. These trends are in line with Nedoluzhko and Agadjanian (2015).

Figure 1: Incidence of marriage types by year of marriage

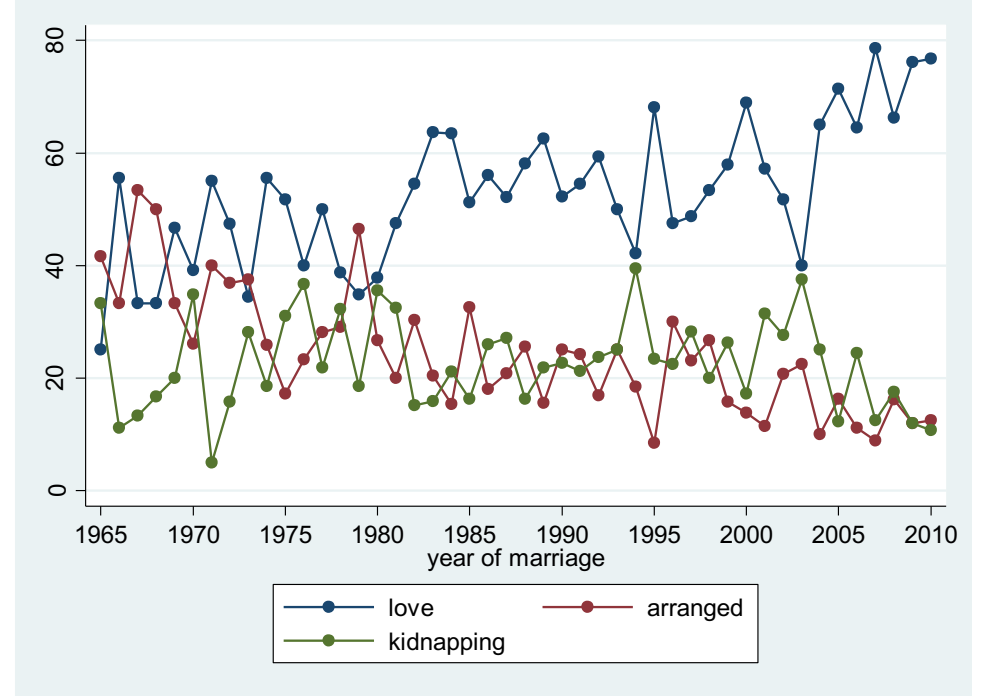

Source: Authors' illustration based on 2011 LIK data.

Female respondents were also asked about their own and their husband's ages at marriage, whether their parents received a bride price, whether they ever gave birth, and detailed information on their children. Children's birth weight was recorded based on the mother's recall. During the Soviet Union and also in today's Kyrgyzstan, birth weight is recorded on a so-called health card for each child. This health card is used to document all medical information during a child's development. Health cards used to be kept at hospitals or health centers but increasingly are stored at home. We expect that younger women more accurately recall their children's birth weight. For this reason, we split our sample of women at median age (43 years) and conduct the analysis only for children born to women aged 18-43 years. We also expect women with few - say, up to two children to better recall their children's birth weight. We therefore rerun our analysis for the subset of women with a maximum of two children in the robustness section.

The empirical analysis uses the sample of Kyrgyz women who live outside of Bishkek and Osh city, were ever married, are of the age group 18-43 years at the time of the survey, and gave birth to at least one child. We exclude women residing above 2500 metres of altitude. The medical literature has found that birth weight is reduced at high altitudes, presumably due to the lower levels of oxygen (Giussani et al., 2001; Jensen and Moore, 1997; Unger et al., 1988). It appears to be unresolved, though, at which levels of altitude this phenomenon sets in. We thus define a different threshold in the robustness section. 


\section{EMPIRICAL METHODOLOGY}

We focus on estimation of the effect of marriage resulting from bride kidnapping on birth outcomes, and specifically on the birth weight of children. The birth weight (measured in grams) of child $i$ born to mother $j$ in district $k$ is a linear function of whether the marriage of that child's parents was a kidnapped marriage or not $\left(K_{j k}\right)$, a set of child $\left(X_{i j k}\right)$ and mother $\left(M_{j k}\right)$ characteristics at the time of birth, and birth date dummies $\left(\gamma_{i}\right)$. The empirical model is given in equation (1):

$$
\text { Birth Weight }_{i j k}=\alpha+\beta_{1} K_{j k}+\beta_{2} X_{i j k}+\beta_{3} M_{j k}+\gamma_{i}+\varepsilon_{i j k}
$$

Child characteristics $\left(X_{i j k}\right)$ capture the gender and the birth order of child $i$. They additionally capture whether child $i$ is a twin (no other multiple births were observed). ${ }^{10}$ Mother characteristics $\left(M_{j k}\right)$ include her age at child $i$ s birth and her educational attainment. A squared term for her age at birth is also included to control for a non-linear relationship between mother's age at birth and birth weight. We control for whether or not a mother speaks both Kyrgyz and Russian and the mother's height, the latter of which has been found to be an important determinant of birth weight (Kramer, 1987). ${ }^{11}$

In the robustness section, we additionally include two control variables, which are available only for a subset of the sample. These variables are the educational attainment of the child's father and the mother's employment status in the year before she gave birth. The LIK survey contains labor market information going back to the year 1989. For women who gave birth after 1989, we can distinguish between women who worked in agriculture, worked in non-agriculture, were enrolled in an education program, and were not in the labor force (housewife or on maternity leave) in the year before giving birth. ${ }^{12}$

$\gamma_{i}$ is a set of fixed effects for child $i$ s birth month and birth year, to control for seasonal variations in birth weight and time trends over the years. $\varepsilon_{i j k}$ is the error term assumed to be orthogonal to birth weight. We cluster the standard errors of this estimation at the mother level. We are interested in the coefficient $\beta_{1}$. If $\beta_{1}$ is negative, mothers married through kidnapping give birth to lighter children. We interpret such a result as reflecting worsened circumstances for these mothers during pregnancy. We examine the specific mechanisms through which kidnapping affects birth weight below.

Kidnapping is not likely a random event. Therefore, equation (1) potentially suffers from endogeneity due to omitted variable bias. Estimates of $\beta_{1}$ would be biased if women ended up in kidnapped marriages based on certain characteristics that we do not control for and that also affect birth weight. For example, if women who appear particularly healthy and who are therefore presumably more fertile were most likely to be kidnapped, our OLS estimates would be biased

${ }^{10}$ We would like to control for gestation duration, but, as in Mansour and Rees (2012), we do not have this information.

${ }^{11}$ Another important determinant is smoking during pregnancy. Very few women smoke in Kyrgyzstan; only 2.5 percent of all adult women in the LIK sample smoke. We therefore do not control for smoking although we know whether women smoked at the time of the survey, but not at the time of pregnancy.

12 The younger generation in our sample was born between 1968 and 1992. The oldest child of a mother in this younger generation was born in 1986. 
towards zero. In order to address the omitted variable bias, we run a two-stage least-squares (2SLS) estimation, using an instrument for kidnapping status.

The anthropological literature explains that the family of the groom plays a crucial role in his decision to kidnap. The groom's parents and siblings usually actively help plan the kidnapping (Amsler and Kleinbach, 1999; Borbieva, 2012). When the groom's family is not informed in advance of the kidnapping, it is engaged when the kidnapped woman enters the groom's house. The female relatives of the groom are expected to persuade the prospective bride to place the marriage scarf on her head. We argue that in areas with a high prevalence of past kidnappings, individual families are more likely to support this practice and may pressure prospective grooms to kidnap. An unmarried woman living in such an area is more likely to be kidnapped and acquiesce to the marriage than a woman in an area with a low prevalence of past kidnappings. We calculate the share of kidnapped marriages among all marriages per district, but only for the generation of women who are older than the median age of 43 years. This older generation of women forms the set of potential mothers-inlaw. We use this information as an instrument for women in the younger generation. ${ }^{13}$

We assume that the district-level share of kidnapping among women in the older generation provides an exogenous source of variation for the marriage selection of younger women in the district (raion). ${ }^{14}$ The older generation does not choose to live in a particular location because of the marriage market that their children face. Whether or not a woman in the young generation still lives in the same province where she was born is not significantly related with the district-level share of kidnapping (regression results unreported). Rural Kyrgyz people are not very mobile, and marriage markets (at least for kidnappings and arranged marriages) are local. In our total sample of adult women (including the younger and older generation) living in rural areas, 89 percent were born in the same province where they lived at the time of the survey. The geographical circumstances that a Kyrgyz woman is born into are thus highly likely to pre-determine her individual probability of having a kidnapped marriage.

The district-level proportions of marriages due to kidnapping range between zero and 0.9 (Appendix Figure A1). In some districts, there is a low number of observations among the older generation of women, which makes the calculation of district-level shares for kidnapped marriages among all marriages unreliable. We therefore exclude districts with less than nine women in the older generation. We lose information on five out of 46 districts. While all observed districts in Naryn province indicate a high prevalence of kidnapped marriages, there are almost no kidnapped marriages reported in Batken province. All other provinces have a wider distribution of district-level shares. In our sample of the younger generation, the mean of this district-level share is 0.29 (with a standard deviation of 0.22 ), and the median is 0.30 .

Our identifying assumption is that the district-level share affects the likelihood of kidnapped marriage of any single woman but does not have an independent influence on her children's birth weight once we control for kidnapping. This may seem questionable if the prevalence of kidnapped marriage is correlated with other district-level characteristics, such as the level of poverty, which also affect children's birth weight. We can eliminate this concern in the following way. Since the Kyrgyz are essentially the only ethnic group in Kyrgyzstan that practices kidnapping, we can test for a

13 We are grateful to Priscilla Hermida of Universidad Pontifica Catolica del Ecuador for this suggestion.

${ }^{14}$ According to the 2009 Census (NSC, 2009), the minimum and maximum population sizes in a district are 21,154 and 321,915 people, respectively. The mean is 96,202 . 
relationship between the district-level share of kidnapping and birth weight using data from other ethnic groups. If the district-level share captured other information than simply the prevalence of kidnapped marriages, a correlation between the district-level share and children's birth weight should then show up for the non-Kyrgyz ethnic groups. Appendix Figure A2 illustrates the frequency with which children born to non-Kyrgyz mothers of the age group 18-43 live in districts with varying prevalence of kidnapped marriages. Even though the non-Kyrgyz in our sample do not reside in the districts with the highest kidnapping prevalence, we observe some variation in the district-level share for this group. ${ }^{15}$ We regress the birth weight of non-Kyrgyz children on the district-level share of kidnapping. Table 1 illustrates that there is no association between the district-level share and children's birth weight for the non-Kyrgyz, whether or not we control for child and mother characteristics. ${ }^{16}$

The identifying assumption could still be violated if the district-level prevalence of kidnapped marriage affected a number of pre-marriage characteristics of Kyrgyz women that are also related with children's birth weight. Health, education, and family background are such potential characteristics. We know the women's height, whether or not they suffer from high blood pressure, their proficiency of Kyrgyz and Russian, and whether or not their fathers worked in agriculture. We also know the highest education degree obtained by the women. However, schooling is not necessarily finished by the time of marriage, which is why we prefer the language variable as an alternative indicator of education. We consider maternal height, blood pressure, language proficiency and father's agricultural employment to be determined before marriage age and to potentially influence children's birth weight (Huxley et al., 2002; Kramer, 1987). We estimate the relationship between these variables and the district-level share of kidnapping for the sample of the younger generation women and report the results in Table 2. There is no association between the four variables and the prevalence of kidnapped marriage in a district.

Last but not least, the validity of the instrument would be questionable if the kidnapping husbands were in any way different from the husbands involved in non-kidnapped marriages. If, for example, the least educated or the unemployed were more likely to kidnap than to engage in arranged or love marriages, this could have consequences on children's birth weight through the level of health care or the quality of nutrition that the pregnant women enjoy. As indicated above, earlier studies have not found any relationship between the level of education or the economic activity of the husband and his likelihood to kidnap (Handrahan, 2004; Nedoluzhko and Agadjanian, 2015). ${ }^{17}$ In Table A1 in the Appendix, we show a cross-tabulation of the educational attainment of the husbands of our younger generation sample (as well as of the wives themselves) and the type of

\footnotetext{
${ }^{15}$ The non-Kyrgyz in this analysis live in 26 out of 41 different districts for which we calculated the districtlevel share of kidnapping.

${ }^{16}$ We combine all non-Kyrgyz ethnic groups. The same result emerges when we restrict consideration to Uzbeks, the largest minority group.

${ }^{17}$ The results by Nedoluzhko and Agadjanian (2015) may seem confusing in this regard. The authors conduct event-history analysis to estimate the risks of entry into marriage. They report that men with a higher educational level face a higher risk of kidnapping, especially forced kidnapping, than men with a lower educational level. Yet, better educated people are generally more likely to be married, either through kidnapping, arranged marriage or otherwise. There is no indication that education matters for the choice of marriage type.
} 
marriage. ${ }^{18}$ Whereas educational attainment is similar for husbands in kidnapped marriages and arranged marriages, it differs for husbands in love marriages. There is a substantially higher share of husbands with a university degree in love marriages than in the other types of marriage. This difference might have consequences on children's birth weight, for example through the quality of health care or nutrition provided to the wives. Therefore (and for other reasons elaborated on below), we drop love marriages and only compare children born to mothers in kidnapped marriages with children born to mothers in arranged marriages.

In addition to the IV estimation, we run the OLS estimation of equation (1) and include district fixed effects. By doing so, we compare women in kidnapped and arranged marriages within the same district to each other. We thereby control for heterogeneity between districts, such as different poverty rates or the availability of medical facilities. This estimation is an alternative approach to measuring the effect of kidnapped marriage on birth weight and it represents an additional test for whether or not the district-level share of kidnapping captures unobserved district characteristics. If it did, the results of the OLS estimation including district fixed effects would be substantially different from the OLS estimation without these fixed effects and instead close to the IV estimates. The estimation is given by equation (2):

$$
\text { Birth Weight }_{i j k}=\alpha+\beta_{1} K_{j k}+\beta_{2} X_{i j k}+\beta_{3} M_{j k}+\gamma_{i}+\tau_{k}+\varepsilon_{i j k}
$$

where $\left(\tau_{k}\right)$ are the district fixed effects.

\section{Descriptive Statistics}

In our empirical analyses, we ignore women who report love marriages and focus on outcomes for women in kidnapped marriages and women who had arranged marriages. We consider arranged marriages to be the adequate reference group for kidnapped marriages for several reasons. First, there is a greater share of husbands and wives with a university degree in love marriages than in the other types of marriage (Table 2). A similar picture emerges with regard to language proficiency. Husbands and wives are more likely to speak both Kyrgyz and Russian in love marriages than in other marriages. This difference in education is worrying because, on the one hand, it suggests a selection of more educated individuals into love marriage and, on the other hand, it might have consequences for birth outcomes - for example, through the nutrition and health care that pregnant women receive.

Second, there seems to be selection in terms of marriage age as well. The age gap between spouses is smaller in love marriages (3.4 years) than in arranged marriages (4.8 years) and kidnapped marriages (4.9 years). The spousal age gap has often been used as a proxy for women's bargaining power within the household (Browning et al., 1994; Vermeulen, 2005). In line with this argument, bargaining power is systematically differently distributed in love marriages compared with kidnapped and arranged marriages.

\footnotetext{
${ }^{18}$ We have information on educational attainment for only 612 husbands out of the sample of 703 women in the younger generation sample.
} 
Third, compared to the numbers in Nedoluzhko and Agadjanian (2015), the prevalence of kidnapped marriages observed in our data seems too low. These authors report that one third of all marriages of Kyrgyz women in an age group comparable to our younger generation sample were the result of kidnappings. We measure slightly less than one quarter. It seems unlikely to us that unreported kidnapped marriages are categorized as arranged marriages in the LIK data because arranged marriages are a particular, well-defined type of marriage. We expect unreported kidnapped marriages to be categorized as love marriages, which is especially probable the more kidnappings are consensual. This means that while reported kidnapped marriages are likely to be true kidnapped marriages (with varying degrees of force involved in the kidnapping process) and reported arranged marriages are likely to be true arranged marriages, reported love marriages are likely to contain some marriages resulting from non-consensual and consensual kidnappings. ${ }^{19}$

Table 3 provides summary statistics on the variables included in equation (1), distinguished by marriage type. ${ }^{20}$ These statistics are for the total sample in columns (1) and (2) as well as for the younger generation in columns (3) and (4). In the upper panel of the table, we report summary statistics for the children born to the mothers in our sample; in the lower panel for the mothers themselves. Among kidnapped and arranged marriages, some children (21 children among mothers in kidnapped marriages and 15 children among mothers in arranged marriages) seem to be born out of wedlock; the year of birth is reportedly before the year of marriage. We include these children in our analysis. In the robustness section, we exclude them because pregnancy may be differently experienced by unmarried women than by married women.

The total sample comprises 670 women who gave birth to 2,568 children. Among the younger generation, 282 women gave birth to 828 children. For both the total sample and the younger generation, mean birth weight is significantly lower by 114 grams and 92 grams, respectively, for children in kidnapped marriages than for children in arranged marriages. Figure 2 displays the full distribution of birth weight for children born to the mothers in the younger generation. Mean birth weight is slightly higher for children in arranged marriages, as is clear from Table 2, but the standard deviation is also higher. ${ }^{21}$ There are differences neither in the share of male and female children across the marriage types nor in the share of children who are the firstborn. This indicates that the average number of children is comparable across the marriage types - 2.9 for kidnapped marriages and 3.0 for arranged marriages among the younger generation of mothers.

\footnotetext{
19 We expected a relationship between the prevalence of kidnapped marriages and the prevalence of arranged marriages within districts. We thus calculated district-level shares of kidnapped and arranged marriages for the young generation. The correlation is -0.22 , but not statistically significant $(p=0.17)$. Among the older generation, the correlation is much higher at $-0.42(\mathrm{p}=0.01)$.

${ }^{20}$ Father's educational attainment is not included in this table but can be inferred from Table A1 in the Appendix.

${ }^{21}$ Only 2.4 percent of children born in kidnapped marriages were born with low birth weight, defined as weight below 2,500 grams, and 6.6 percent of children born in arranged marriages. These shares relate to the younger generation. The respective shares are 4.4 percent and 4.0 percent in the older generation.
} 
Figure 2: Birth weight distribution

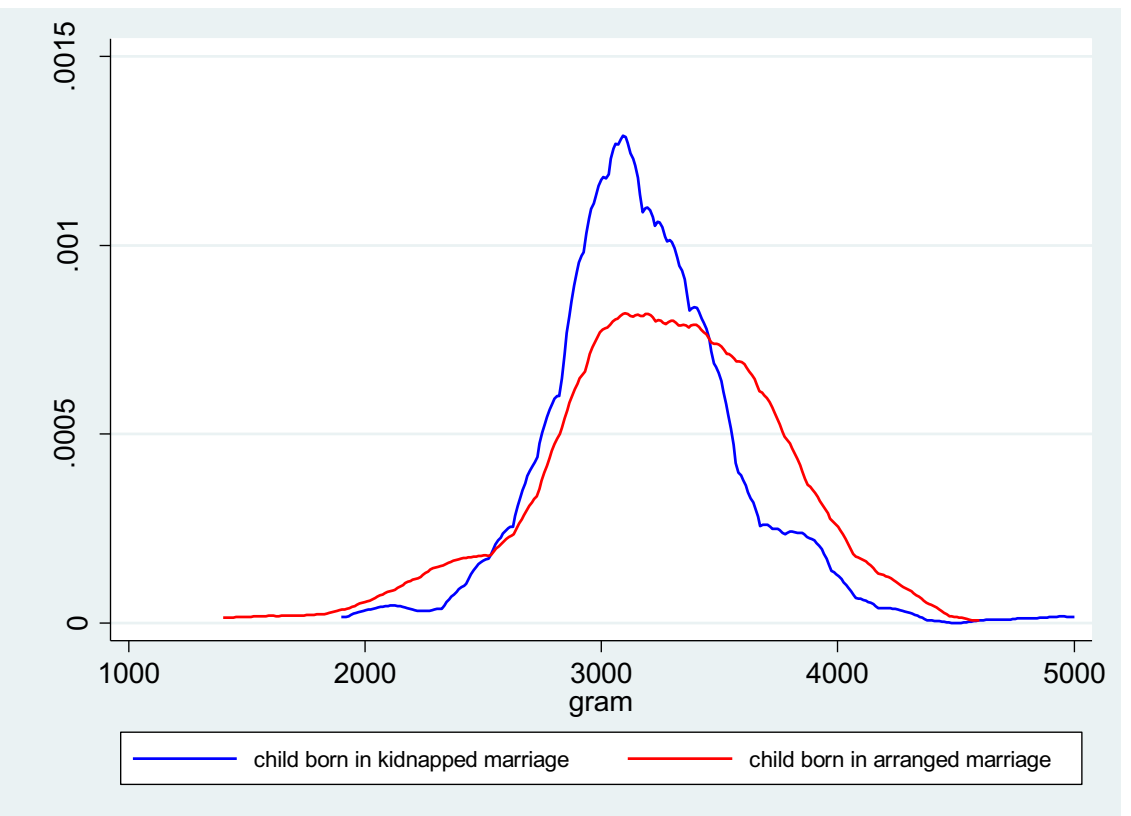

Source: Authors' illustration based on 2011 LIK data.

Kidnapped mothers differ from mothers in arranged marriages on several counts. Kidnapped mothers are slightly younger at the time of birth. This is true for both the average age at birth (for all children) as well as for age at birth of the first child. Lower age at birth among kidnapped mothers may reflect the fact that they are also younger at the time of marriage than women in arranged marriages. Regardless of the marriage type, however, the first child is born 1.6 years after marriage among the younger generation sample. ${ }^{22}$ There is a larger share among kidnapped mothers than among arranged marriage mothers with only basic education (among the younger generation), and there is a smaller share among kidnapped mothers than among arranged marriage mothers with a secondary school degree. It is important to note that kidnapped and arranged marriages are rare at very young ages; most marriages occur between 17 and 25 years of age. Hence, both types of marriage do not target very young girls but rather young women who have finished most if not all of their education. ${ }^{23}$ Kidnapped mothers seem to be significantly less likely to work in agriculture and more likely to be students before giving birth.

We face the risk to capture unobserved differences between mothers in kidnapped and arranged marriages in terms of health endowments, which could have an impact on children's birth weight. In order to address this risk, we implement a number of placebo tests. We regress maternal height and, alternatively, a number of chronic health conditions on the type of marriage, the woman's age at

\footnotetext{
${ }^{22}$ The time between marriage and giving birth is not exact, as we do not have information about the month in which people married.

${ }^{23}$ We have been told (by Aliya Ibragimova and Christopher Edling) that secondary school and university graduation ceremonies are a popular time for kidnapping. Families of the groom often promise to pay for the bride's education, so marrying after graduation reduces the costs for the groom's family. The results presented in Nedoluzhko and Agadjanian (2015) are consistent with this claim: being in school more than halves one's risk of incurring either a forced or staged kidnapping.
} 
marriage, her educational attainment, her language proficiency and district fixed effects. The assumption is that maternal height and (most) chronic illnesses are determined before marriage age and should therefore be unaffected by own marriage type. Results can be found in Table 4 . Kidnapping does not appear to be related with height or chronic illness (except for kidney disease).

\section{Estimation RESUlts}

Table 5 provides OLS (column (1)) and IV (column (2)) results for estimating equation (1) as well as OLS (column (3)) results for equation (2). The number of observations is slightly lower in column (2) than in columns (1) and (3) because we cannot produce reliable numbers for the districtlevel share of kidnapping for all districts (when the number of women in the older generation is too low within the district to compute the instrument). ${ }^{24}$

Results for the control variables provide a plausible picture of the determinants of birth weight in Kyrgyzstan. Male children are born with significantly higher weight (64-91 grams) than female children, and twins have significantly lower weight (806-865 grams) than singletons. Firstborns tend to be born with lower weight compared with children of higher birth order, but this finding is not statistically significant. ${ }^{25}$ Mother's age does not matter, or only at a marginal level of significance in column (3). We believe this is due to the fact that women give birth at an average age of 24-25 years or 21-22 years for the first child. Age at birth is not very high and therefore does not imply agerelated risks of short gestation duration and low birth weight. Maternal age at first birth is also not very variable relative to many other countries; the standard deviation is 3 years. Furthermore, we find that while formal schooling degrees are unrelated to birth weight, speaking two languages, which we regard as an alternative indicator of education, increases birth weight by 103 grams in column (3). Mother's body height is positively but insignificantly related with birth weight.

Ceteris paribus, mothers in kidnapped marriages give birth to significantly lower birth weight children compared with mothers in arranged marriages. The birth weight loss is 121 grams in column (1), 228 grams in column (2), and 95 grams in column (3). The difference between the OLS estimate in column (1) and the IV estimate in column (2) suggests that there is some unobserved variable, for example physical attractiveness or healthy appearance of the woman, which is positively related with both kidnapping and birth weight. Such a variable will be included in the error term in the OLS estimation, resulting in biased estimates. There clearly appears to be such an unobserved variable, not at the level of the district but at the level of the individual woman, or possibly at the level of the household. If the bias were due to district-level variation, the results in columns (1) and (3) should be substantially different, but they are, in fact, relatively close to each other.

Table A2 in the Appendix reports the first-stage results related to the IV estimation. The districtlevel share of old generation kidnappings is a strong predictor of a woman's likelihood of being in a kidnapped marriage. A 10 percentage point increase in the district-level share increases the likelihood of marriage through kidnapping of an individual woman by 14 percentage points. Tests

\footnotetext{
${ }^{24}$ The reduced sample size does not modify the results by much: running the OLS estimation for the sample of column (2) leads to a kidnapping coefficient of -139.2, significant at the 1 percent level.

25 It is a standard finding that firstborn children are lighter than other children (Kramer, 1987). We also differentiated between children of higher birth order, but this comparison did not increase the explanatory power of the estimation.
} 
for the relevance of the instrument reveal that the instrument is not weak. The F-statistic of the test for the significance of the excluded instrument (the district-level share of kidnapping) is 127 at a $\mathrm{p}$ value of 0.00 . The partial $R^{2}$ is 0.276 compared to an adjusted $R^{2}$ of 0.338 .

We run a number of robustness tests in which we follow the same approach as in Table 5; we report the OLS and IV estimates of equation (1) and the OLS estimates of equation (2) in Table 6. First, we exclude the 36 children born out of wedlock (columns (1)-(3)). Excluding these children matters for the magnitude of the coefficients, but the change in the magnitude is rather small. Second, we exclude all observations residing above an altitude of 2,000 meters (columns (4)-(6)). This exclusion is because we cannot be sure that the threshold, above which birth weight decreases with altitude is 2,500 meters as assumed so far. The results are essentially unchanged, compared with those in Table 5.

Third, we control for the employment status of the child's mother in the year before giving birth (column (7)-(9)), distinguishing between work in agriculture, work in non-agriculture, enrollment in an education program, and not being in the labor force (housewife or on maternity leave). This additional control changes the magnitude of our results only marginally. Fourth, we control for the educational attainment of the child's father (column (10)-(12)), again seeing no major deviations from the earlier results.

Fifth, we only consider children born to women who had a maximum of two births (columns (13)-(15)). We believe that women with fewer children are better able to recall the birth weight of their children correctly. This change reduces the sample size considerably, but it also explains more of the variation in the birth weight variable than any previous estimation model. The interesting finding is that the kidnapping coefficients for the OLS estimations in columns (1) and (3) are now much larger: Kidnapping seems to result in a loss in birth weight of close to 200 grams.

Sixth, we define the cutoff between the young and the old generation differently (columns (16)(18)). In the previous estimation, we used the median age in our total sample of women as the cutoff; we now draw the limit at marriage in 1992 - the first year of Kyrgyzstan's independence from the Soviet Union. We make this change to account for the fact that marriage formation may have changed from 1992 onwards. We could imagine that greater socialization in the Soviet Union meant a far lower incidence of non-consensual kidnapping. Schooling was nearly universal in Soviet times, as was participation in youth organizations like the Young Pioneers (Kuehnast, 1998). Almost all young men and women were exposed to many people of the opposite sex and in an environment that did not discourage romantic entanglements. With the dissolution of the Soviet Union, such institutionalized interaction among the youth disappeared. The extent of force involved in kidnappings likely increased after 1992. For the IV analysis, we calculate the district-level share of kidnapping on the basis of information from women who were married in 1991 or earlier and run the estimation with the sample of women who were married in 1992 or later. The estimates in columns (16) and (17) are negative and significant as before and in the area of a birth weight loss of around 100 to 200 grams. The estimate in column (18) is no longer statistically significant (t-value = -1.46). In essence, these results provide no evidence that substantially more kidnappings were nonconsensual after the dissolution of the Soviet Union.

Overall, our findings indicate a strongly negative impact of kidnapped marriages on the birth weight of children. The magnitude of the impact appears to be between 100 and 200 grams, which is sizable. The impact is in line with the very limited empirical evidence that exists on violence against 
women and newborn health. Most critically, Aizer (2011) finds that admission to a hospital for assault during pregnancy reduces birth weight by 163 grams among Californian women. Our findings are difficult to compare to the other studies on stress and birth weight that we reviewed above. These studies investigate sources of stress, such as land mine explosions or a macroeconomic crisis, all of which can undoubtedly lead to serious worries and high stress levels among the affected women. Yet, the stress affects the whole household, not just the women, and spouses might, in fact, support and comfort each other.

\section{IDENTIFYING THE CHANNELS}

Does the measured birth weight loss resulting from kidnapped marriage work through psychosocial stress as we hypothesize? We identified strenuous physical work, poor nutrition, insufficient prenatal care, and short birth intervals as possible alternative channels and now provide evidence, to the extent possible, for each of them.

Given that the LIK dataset contains information about time use, we can compare how women in kidnapped and arranged marriages spend their days. This gives insight into whether women in kidnapped marriages are doing more strenuous physical work, get less sleep, and less leisure. This information refers to the time of the survey, not the time of pregnancy. It therefore does not allow for any causal explanations between time use and birth weight. The time use data can nevertheless give an indication about how different women spend their days on average. Appendix Table A3 reports average hours spent per day on different activities, separately for women in kidnapped and arranged marriages. There is no evidence that women in kidnapped marriages are disadvantaged in terms of time use. They spend slightly more time for personal care and less time for elderly care. Fewer women live with their mother-in-law in kidnapped than in arranged marriages, partly due to the higher divorce rate among women in kidnapped marriages (see below). But even if we compare time use of only women in kidnapped and arranged marriages who live with their mother-in-law in the same household (unreported), there are no significant differences in time use. We conclude that strenuous physical work does not seem to be the main channel between kidnapped marriage and birth weight. ${ }^{26}$

The LIK survey lacks information on prenatal care during pregnancy. However, we know from the Demographic and Health Survey in Kyrgyzstan that 97 percent of women received prenatal care from a skilled provider and 98-99 percent of births were delivered by a skilled provider in 1997 and 2012 (NSC, 2013). Such high coverage makes it unlikely that the lower birth weight among children in kidnapped marriages is due to insufficient prenatal care.

We know the birth months and years of the children born to our sample women and can also compare birth intervals. We do not know the day of birth and assume it is the first of each month. We calculate the number of days between the first and the second child, the second and the third child, and so on. The number of women decreases as we increase the birth order and we only show the average number of days between births up to the fourth child. The results are shown in Table

${ }^{26}$ Of course, this information only refers to the amount of time spent in a specific activity and tells nothing about the intensity of doing it. For example, five hours of housework alone may be more strenuous than doing five hours of housework jointly with another person. Still, the overall picture that we get from the time use information does not lead us to believe that kidnapped women suffer from more strenuous work. 
A4. There is no difference in birth intervals between children born to mothers in kidnapped versus arranged marriages, making us confident that kidnapped marriage does not affect birth weight through differences in birth spacing. ${ }^{27}$

This leaves us with poor nutrition during pregnancy as the final alternative channel. Unfortunately, the LIK does not include any information on nutrition that helps to shed light on the plausibility of this channel. We think it is unlikely that husbands provide poor nutrition to their kidnapped wives when they are pregnant because being married and having children is socially so important. We do not have any hard facts to prove this.

\section{SuPPORTING EVIDENCE}

Our confidence in the hypothesis that bride kidnapping is involuntary and that it affects women and their infants via a stress mechanism is strengthened by two additional pieces of evidence. These are presented mainly as corroborating descriptive support, since in one case (divorce) the sample size is small given the relative infrequency of the event, and in the other case (assortative mating) we do not develop hypotheses as to which features are most important, and which should be positively or negatively assorted.

Overall, the divorce rate is 12.2 percent among kidnapped women and 4.8 percent among women in arranged marriages in our younger generation sample. This is a huge difference; when in an OLS regression (Table 7) we control for other characteristics, none of which turns out to be significant as a predictor of divorce, the coefficient on being kidnapped becomes even larger (10.8 percentage points). It is possible that the sort of people who elope impetuously also would be more likely to divorce, so that unobserved heterogeneity cannot be excluded. However, the huge coefficient size when we condition on observables makes this a less obvious explanation than, alternatively, that many kidnapped women were desperately unhappy.

Divorce is a considerably more precipitous and traumatic move for rural Kyrgyz and other Central Asian women than it is for their Western counterparts, or even their urban counterparts in Kyrgyzstan. The strong, negative effect on satisfaction with family life appears in Table 7 as well, and once again none of the controls has a significant effect. Nor, for that matter, does being kidnapped. However, an interaction term between being kidnapped and being divorced is large and negative as well, and doubles the divorce effect. This pattern is consistent with an event that is consensual for some (that is, an elopement) and not for others (that is, an involuntary kidnapping).

In addition, the LIK asked individuals to self-assess their personality: It includes a 21-item questionnaire on the Big-5 personality traits. Individuals were asked to indicate on a 5-point scale to what extent they agreed with statements such as: I see myself as someone who keeps distance. We have answers from 235 couples (115 in arranged marriage, 120 in kidnapped marriage) on these questions and use them to see whether spouses in kidnapped marriage are more different from one another than spouses in arranged marriage. We assume that larger differences imply poorer spousal match

\footnotetext{
${ }^{27}$ We need to make one important qualification to this conclusion. We only know the birth dates of live-born children, as the LIK did not collect information about stillborn children. Hence, the conclusion only holds under the assumption that kidnapped women do not have more stillborn children than arranged marriage women on average. We do not have any evidence that this would be the case.
} 
and, hence, more stress involved in the marriage. Our point of departure lies in standard marriage models (and, specifically, Becker, 1973), which imply that in mutually voluntary marriage, there should be positive assortative mating (PAM) on complementary characteristics such as outlook on life, value placed on children's human capital, and willingness to accept risks. If kidnapping is merely a form of ceremonial elopement, then patterns of assortative mating should not differ for those kidnapped and those whose marriages were arranged or the outcome of romances.

We compute dummy variables taking the value 1 if the self-assessment of husbands and wives on a certain question differs by a maximum of one point on the 5-point scale, and the value 0 if it differs by more than one point. Table 8 illustrates the share of couples whose self-assessment is identical or differs by a maximum of one point. For nearly all (19 out 21) questions, there is lower similarity between husbands and wives in kidnapped than in arranged marriage. Note that if poorer outcomes (lower birth weights, higher divorce risk, lower life satisfaction) were actually due to elopement by impetuous, immature, hyperbolic discounters rather than to involuntary kidnapping, then we should see an unusually high level of positive assortativeness. In particular, note that there is much less concordance between spouses in kidnapped marriage than other types in response to the statement I see myself as someone who makes plans and follows through on them - and elopement would obviously qualify as a major life plan.

\section{CONCLUSION}

We consider the effects of marriage resulting from bride kidnapping, a common practice in Kyrgyzstan and several other countries, on birth outcomes. We show that infants born to women in kidnapped marriages have significantly lower birth weight than infants born to women in arranged marriages. The magnitude of the birth weight loss is in the range of 100 to 200 grams. We interpret this result as evidence that kidnapping involves some degree of force, on average, leading to poorer quality of the resulting marriage and higher psycho-social stress for the women involved.

Kidnapping may be fully consensual between the groom and the bride. However, if this was true for all kidnappings, we would not obtain the results shown here. This is important news for Kyrgyzstan, and potentially for the other countries where some marriages result from kidnapping. Many human rights organizations in Kyrgyzstan have tried to raise awareness about the practice of kidnapping and to encourage Kyrgyz women and their families to report kidnappings to the authorities. Social condemnation of the practice is on the rise, at least in urban areas, and the country recently became more serious about law enforcement in this context. In contrast, there is virtually no law enforcement in South Africa (Nkosi and Buthelezi, 2013; Rice, 2014), no capacity to investigate kidnappings in Ethiopia (Dito, 2015), and complete official denial in Armenia (Edling, 2012). Most incredibly, the Russian Duma (which has authority over Chechnya, Dagestan, and Ingushetia where kidnapping is also practiced) declined in 2006 to authorize investigative responsibility by the state into cases of bride kidnapping because the law excluded cases in which men were kidnapped for similar purposes (Sirazhudinova, 2013). ${ }^{28}$

\footnotetext{
${ }^{28}$ These societies are also characterized by various levels of denial of the extent of coercive abduction, or refusal by the state to seriously investigate kidnappings. Remarkably, the exception to this statement comes from Chechnya, where President Ramzan Kadyrov has taken the offensive against bride kidnapping, imposing a 1-million ruble fine on kidnappers and also de-registering Islamic religious authorities who seek to reconcile kidnapped women to accept their married fate (Serdyukova, 2011; Sirazhudinova, 2013).
} 
Our findings make clear that the women in kidnapped marriages and their children are adversely affected by this practice. An important question for further research is to investigate the long-term consequences of kidnapped marriage for children born to kidnapped mothers. The good news is that the incidence of low birth weight (below 2500 or 1500 grams) is not higher in kidnapped marriages compared with arranged marriages, implying that the losses are occurring among infants who are not already at elevated risk of health and development problems. However, it is important to recognize that birth weight losses, even if from an average level of birth weight, can have long-term effects, including higher neonatal and infant mortality, lower school completion, and lower wages in adult life (Black et al., 2007; Camacho, 2008).

In further research, it would be interesting to also investigate when and why some kidnappings do not end in marriage. The topic also is one that invites exploration of its social efficiency characteristics from a global (or, more aptly, village) perspective. We have argued heuristically that it seems rational for individual young men to consider coercively kidnapping brides. It also may be rational for potential brides to expose themselves to the risk of being kidnapped while they search for better husbands. But kidnapping has external effects, both on marriage choices of other individuals, and on the health of offspring and wives that does not get fully captured in individual agents' calculations. The fact that kidnapping persists in a small but non-negligible collection of diverse settings means either that the externalities are not unacceptably large, or that there are positive features of a mating system that includes a kidnapping option.

Most obviously, marriage markets that include a kidnapping option are likely to clear more rapidly than other systems, especially those restricted to uncertain lovers. Societies that have limited opportunities for young women and men to meet and develop both experience and preferences over partners therefore may value arranged or kidnapped marriages. If arrangements often fail, perhaps because of a combination of high value placed on brides - and hence high bride prices - and significant social stratification, then kidnapping may not automatically be socially condemned. This is particularly likely to be true if the myth of non-calamitous outcomes is maintained. 


\section{REFERENCES}

Aizer, A., 2011. Poverty, Violence, and Health: The Impact of Domestic Violence during Pregnancy on Newborn Health. Journal of Human Resources 46, 518-538.

Almond, D., Currie, J., 2011. Killing me Softly: The Fetal Origins Hypothesis. Journal of Economic Perspectives 25, 153-172.

Almond, D., Mazumder, B., 2011. Health capital and the prenatal environment: the effect of Ramadan observance during pregnancy. American Economic Journal: Applied Economics 3, 56-85.

Amsler, S., Kleinbach, R., 1999. Bride Kidnapping in the Kyrgyz Republic. International Journal of Central Asian Studies 4, 185-216.

Ayres, B., 1974. Bride Theft and Raiding for Wives in Cross-Cultural Perspective. Anthropological Quarterly 47, 238-252.

Banerjee, A., Duflo, E., Ghatak, M., Lafortune, J., 2013. Marry for What? Caste and Mate Selection in Modern India. American Economic Journal: Microeconomics 5, 33-72.

Barnes, R.H., 1999. Marriage by Capture. Journal of the Royal Anthropological Institute 5, 57-73.

Batabyal, A.A., 2001. On the Likelihood of Finding the Right Partner in an Arranged Marriage. The Journal of Socio-Economics 30, 273-280.

Batabyal, A.A., 1999. A Dynamic and Stochastic Analysis of Decision Making in Arranged Marriages. Applied Economics Letters 6, 439-442.

Batabyal, A.A., 1998. Aspects of Arranged Marriages and the Theory of Markov Decision Processes. Theory and Decision 45, 241-253.

Bates, D.G., 1974. Normative and Alternative Systems of Marriage among the Yörük of Southeastern Turkey. Anthropological Quarterly 47, 270-287.

Becker, G.S., 1991. A Treatise on the Family. Harvard University Press.

Becker, G.S., 1974. A Theory of Marriage: Part II. Journal of Political Economy 82, 11-26.

Becker, G.S., 1973. A Theory of Marriage: Part I. Journal of Political Economy 81, 813-846.

Behrman, J.R., Rosenzweig, M.R., 2004. Returns to Birthweight. The Review of Economics and Statistics $86,586-601$.

Black, S.E., Devereux, P.J., Salvanes, K.G., 2007. From the Cradle to the Labor Market? The Effect of Birth Weight on Adult Outcomes. The Quarterley Journal of Economics 122, 409-439.

Bonzini, M., Coggon, D., Palmer, K.T., 2007. Risk of prematurity, low birthweight and pre-eclampsia in relation to working hours and physical activities: a systematic review. Occupational and Environmental Medicine 64, 228-243.

Borbieva, N.O., 2012. Kidnapping Women: Discourses of Emotion and Social Change in the Kyrgyz Republic. Anthropological Quarterly 85, 141-169.

Bozzoli, C., Quintana-Domeque, C., 2014. The Weight of the Crisis: Evidence from Newborns in Argentina. Review of Economics and Statistics 96, 550-562.

Browning, M., Bourguignon, F., Chiappori, P.-A., Lechene, V., 1994. Income and outcomes: A structural model of intrahousehold allocation. Journal of political Economy 1067-1096.

Browning, M., Chiappori, P.-A., Weiss, Y., 2014. Economics of the Family. Cambridge University Press.

Brück, T., Esenaliev, D., Kroeger, A., Kudebayeva, A., Mirkasimov, B., Steiner, S., 2014. Household Survey Data for Research on Well-Being and Behavior in Central Asia. Journal of Comparative Economics 42, 819-835.

Camacho, A., 2008. Stress and Birth Weight: Evidence from Terrorist Attacks. American Economic Review 98, 511-515.

Dito, B.B., 2015. Women's Intrahousehold Decision-Making Power and Their Health Status: Evidence from Rural Ethiopia. Feminist Economics 21, 168-190. 
Edling, C., 2012. Bride Kidnapping, Courtship, and Marriage in Armenia. Goris Women's Development Resource Center, Yerevan.

Edlund, L., Lagerlöf, N.P., 2006. Individual versus Parental Consent in Marriage: Implications for IntraHousehold Resource Allocation and Growth. The American Economic Review 96, 304-307.

Fafchamps, M., Quisumbing, A., 2008. Household Formation and Marriage Markets in Rural Areas, in: Schultz, T.P., Strauss, J. (Eds.), Handbook of Development Economics, Vol. 4. Elsevier, Amsterdam.

Foureaux Koppensteiner, M., Manacorda, M., 2016. Violence and birth outcomes: Evidence from homicides in Brazil. Journal of Development Economics 119, 16-33.

Giussani, D.A., Phillips, P.S., Anstee, S., Parker, D.J.P., 2001. Effects of Altitude versus Economic Status on Birth Weight and Body Shape at Birth. Pediatric Research 49, 490-494.

Grossman, M., Joyce, T.J., 1990. Unobservables, Pregnancy Resolutions, and Birth Weight Production Functions in New York City. Journal of Political Economy 98, 983-1007.

Handrahan, L., 2004. Hunting for Women. International Feminist Journal of Politics 6, 207-233.

Handrahan, L., 2000. Implications of International Human Rights Law and Bride Kidnapping in Kyrgyzstan. The Fletcher Journal of Development Studies 16, 1-13.

Hobel, C., Goldstein, A., Barrett, E.S., 2008. Psychosocial stress and pregnancy outcome. Clinical obstetrics and gynecology 51, 333-348.

Human Rights Watch, 2006. Reconciled to Violence. State Failure to Stop Domestic Abuse and Abduction of Women in Kyrgyzstan.

Huxley, R., Neil, A., Collins, R., 2002. Unravelling the fetal origins hypothesis: is there really an inverse association between birthweight and subsequent blood pressure? The Lancet 360, 659-665.

Jensen, G.M., Moore, L.G., 1997. The Effect of Altitude and other Risk Factors on Birth Weight: Independent or Interactive Effects? American Journal of Public Health 87, 1003-1007.

Kleinbach, R., Ablezova, M., Aitieva, M., 2005. Kidnapping for Marriage (ala kachuu) in a Kyrgyz Village. Central Asian Survey 24, 191-202.

Kramer, M.S., 1987. Determinants of Low Birth Weight: Methodological Assessment and Meta-Analysis. Bulletin of the World Health Organization 65, 663-737.

Kuehnast, K., 1998. From pioneers to entrepreneurs: young women, consumerism, and the "world picture"in Kyrgyzstan. Central Asian Survey 17, 639-654.

Mansour, H., Rees, D.I., 2012. Armed Conflict and Birth Weight: Evidence from the Al-Aqsa Intifada. Journal of Development Economics 99, 190-199.

McLaren, A.E., 2001. Marriage by Abduction in Twentieth Century China. Modern Asian Studies 35, 953984.

Nedoluzhko, L., Agadjanian, V., 2015. Between Tradition and Modernity: Marriage Dynamics in Kyrgyzstan. Demography 52, 861-882.

Nkosi, M., Buthelezi, M.T., 2013. The nature and causes of bride abduction cases in KwaZulu-Natal, South Africa. Studies on Tribes and Tribals 11, 161-178.

NSC, 2013. Kyrgyz Republic. Demographic and Health Survey 2012. National Statistal Committee of the Kyrgyz Republic, Bishkek.

NSC, 2009. Population and Housing Census of the Kyrgyz Republic of 2009. National Statistical Committee of the Kyrgyz Republic, Bishkek.

Rice, K., 2014. Ukuthwala in Rural South Africa: Abduction Marriage as a Site of Negotiation about Gender, Rights and Generational Authority Among the Xhosa. Journal of Southern African Studies 40, 381-399.

Sirazhudinova, S.V., 2013. Gendernaya Politika v Respublikakh Severnogo Kavkaza: Sovremennye Tendentsii (Gender policy in the republics of the Northern Caucasus: Contemporary trends). Zhenshchina v Rossiiskom Obshchestve (Woman in Russian Society) 1, 14-19. 
Stein, A., Lumey, L., 2000. The Relationship between Maternal and Offspring Birth Weights after Maternal Prenatal Famine Exposure: The Dutch Famine Birth Cohort Study. Human Biology 72, 641-654.

Stross, B., 1974. Tzeltal Marriage by Capture. Anthropological Quarterly 47, 328-346.

Torche, F., 2011. The Effect of Maternal Stress on Birth Outcomes: Exploiting a Natural Experiment. Demography 48, 1473-1491.

Unger, C., Weiser, J.K., McCullough, R.E., Keefer, S., Moore, L.G., 1988. Altitude, Birth Weight, and Infant Mortality in Colorado. Journal of the American Medical Association 259, 3427-3432.

Vermeulen, F., 2005. And the winner is... An empirical evaluation of unitary and collective labour supply models. Empirical Economics 30, 711-734.

Wehby, G.L., Murray, J.C., Castilla, E.E., López-Camelo, J.S., Ohsfeldt, R.L., 2009. Quantile Effects of Prenatal Care Utilization on Birth Weight in Argentina. Health Economics 18, 1307-1321.

Weiss, Y., 1997. The Formation and Dissolution of Families: Why Marry? Who Marries whom? And what Happens upon Divorce, in: Handbook of Population and Family Economics. Elsevier, Amsterdam, pp. 81-123.

Werner, C.A., 2009. Bride Abduction in Post-Soviet Central Asia: Marking a Shift Towards Patriarchy through Local Discourses of Shame and Tradition. Journal of the Royal Anthropological Institute $15,314-331$.

Za Reformy i Rezul'tat, 2015. Mezhdunarodnyi issledovanie obshchestvennoi bezopasnosti v Kyrgyzstane - 2015. Za Reformy i Rezul'tat, Bishkek. 
Table 1: Determinants of birth weight for non-Kyrgyz children

\begin{tabular}{|c|c|c|c|}
\hline \multirow[b]{2}{*}{ District-level share } & \multicolumn{3}{|c|}{ Dependent variable: birth weight } \\
\hline & 78.09 & 31.34 & 14.20 \\
\hline & $(138.2)$ & (139.9) & (139.9) \\
\hline \multirow[t]{2}{*}{ Child male } & . & 27.08 & 33.81 \\
\hline & & $(29.81)$ & $(29.68)$ \\
\hline \multirow[t]{2}{*}{ Child firstborn } & . & $94.96 * *$ & -52.81 \\
\hline & & $(38.80)$ & (41.92) \\
\hline Twin & . & . & . \\
\hline \multirow[t]{2}{*}{ Age at birth } & . & . & 30.61 \\
\hline & & & $(35.84)$ \\
\hline \multirow[t]{2}{*}{ Age at birth squared } & . & . & -0.314 \\
\hline & & & $(0.662)$ \\
\hline \multirow[t]{2}{*}{ Basic education } & . & . & -178.6 \\
\hline & & & $(112.9)$ \\
\hline \multirow[t]{2}{*}{ Secondary education } & . & . & -131.3 \\
\hline & & & $(110.8)$ \\
\hline \multirow[t]{2}{*}{ Technical education } & . & . & $-212.9^{*}$ \\
\hline & & & $(126.3)$ \\
\hline \multirow[t]{2}{*}{ Kyrgyz and Russian } & . & . & -21.61 \\
\hline & & & $(74.30)$ \\
\hline \multirow[t]{2}{*}{ Mother's height } & . & . & 1.699 \\
\hline & & & $(4.159)$ \\
\hline \multirow[t]{2}{*}{ Constant } & $3,208 * * *$ & $3,328 * * *$ & $2,644 * * *$ \\
\hline & $(29.70)$ & (119.0) & $(850.5)$ \\
\hline Birth month \& year FE & $\mathrm{NO}$ & YES & YES \\
\hline Observations & 630 & 630 & 630 \\
\hline R-squared & 0.001 & 0.072 & 0.109 \\
\hline
\end{tabular}

Note: The sample consists of non-Kyrgyz women, who have given birth to at least one child, are of the age group 18-43, do not live in cities, and live below 2500 meters of altitude. Clustered standard errors in brackets.

$* * *$ significant at $1 \%, * *$ at $5 \%, *$ at $10 \%$.

Source: Authors' illustration based on 2011 LIK data. 
Table 2: OLS estimates - Association between district-level prevalence of kidnapping and mother's characteristics

\begin{tabular}{lcccc}
\hline Maternal height & $\begin{array}{c}(2) \\
\text { High blood } \\
\text { pressure }\end{array}$ & $\begin{array}{c}\text { Kyrgyz and Russian } \\
\text { proficiency }\end{array}$ & $\begin{array}{c}\text { Father worked in } \\
\text { agriculture }\end{array}$ \\
\hline District-level share & -1.593 & -0.003 & -0.261 & -0.016 \\
& $(1.944)$ & $(0.014)$ & $(0.234)$ & $(0.121)$ \\
Observations & 703 & & & \\
R-squared & 0.003 & 703 & 703 & 653 \\
\hline
\end{tabular}

Note: The sample consists of ever-married Kyrgyz women, who have given birth to at least one child, are of the age group 18-43, do not live in cities, and live below 2500 meters of altitude.

*** significant at $1 \%, * *$ at $5 \%,{ }^{*}$ at $10 \%$.

Source: Authors' illustration based on 2011 LIK data. 
Table 3: Descriptive statistics, by marriage type

\begin{tabular}{|c|c|c|c|c|}
\hline & \multicolumn{2}{|c|}{ Total sample } & \multicolumn{2}{|c|}{ Young generation only } \\
\hline & (1) & (2) & (3) & (4) \\
\hline & Kidnapped & Arranged & Kidnapped & Arranged \\
\hline \multicolumn{5}{|l|}{ CHILD CHARACTERISTICS } \\
\hline \multirow[t]{2}{*}{ Birth weight } & 3148 & $3262 *$ & 3171 & $3263 *$ \\
\hline & $(410)$ & $(436)$ & $(369)$ & $(490)$ \\
\hline \multirow[t]{2}{*}{ Child male } & 0.519 & 0.528 & 0.510 & 0.525 \\
\hline & $(0.500)$ & $(0.499)$ & $(0.501)$ & $(0.500)$ \\
\hline \multirow[t]{2}{*}{ Child firstborn } & 0.229 & 0.217 & 0.239 & 0.215 \\
\hline & $(0.420)$ & $(0.413)$ & $(0.427)$ & $(0.411)$ \\
\hline \multirow[t]{2}{*}{ Twin } & 0.012 & 0.020 & 0.004 & $0.032 *$ \\
\hline & $(0.107)$ & $(0.138)$ & $(0.067)$ & $(0.176)$ \\
\hline \multirow[t]{2}{*}{ Mother's age at birth } & 26.5 & $27.7 *$ & 24.0 & $25.5^{*}$ \\
\hline & $(6.13)$ & $(6.34)$ & $(4.57)$ & $(4.97)$ \\
\hline Number of observations & 1290 & 1278 & 451 & 377 \\
\hline \multicolumn{5}{|c|}{ MOTHER CHARACTERISTICS } \\
\hline \multirow[t]{2}{*}{ Age at first birth } & 22.3 & 22.8 & 21.0 & $22.3 *$ \\
\hline & $(4.22)$ & $(4.85)$ & $(2.72)$ & $(3.57)$ \\
\hline \multirow[t]{2}{*}{ Age at marriage } & 19.7 & $20.7^{*}$ & 19.4 & $20.7 *$ \\
\hline & $(4.36)$ & $(5.08)$ & $(2.64)$ & $(3.44)$ \\
\hline \multirow[t]{2}{*}{ Basic education } & 0.142 & 0.147 & 0.090 & $0.024 *$ \\
\hline & $(0.350)$ & $(0.354)$ & $(0.267)$ & $(0.152)$ \\
\hline \multirow[t]{2}{*}{ Secondary education } & 0.584 & $0.688^{*}$ & 0.628 & $0.803^{*}$ \\
\hline & $(0.493)$ & $(0.464)$ & $(0.485)$ & $(0.399)$ \\
\hline \multirow[t]{2}{*}{ Technical education } & 0.183 & $0.086^{*}$ & 0.192 & 0.110 \\
\hline & $(0.387)$ & $(0.280)$ & $(0.395)$ & $(0.314)$ \\
\hline \multirow[t]{2}{*}{ University education } & 0.073 & 0.067 & 0.090 & 0.063 \\
\hline & $(0.260)$ & $(0.251)$ & $(0.287)$ & $(0.244)$ \\
\hline \multirow[t]{2}{*}{ Kyrgyz and Russian } & 0.471 & 0.419 & 0.538 & 0.559 \\
\hline & $(0.500)$ & $(0.494)$ & $(0.500)$ & $(0.498)$ \\
\hline \multirow[t]{2}{*}{ Mother's height } & 1.62 & 1.63 & 1.62 & 1.63 \\
\hline & $(0.061)$ & $(0.068)$ & $(0.056)$ & $(0.70)$ \\
\hline \multirow[t]{2}{*}{ Agriculture before birth ${ }^{\text {a) }}$} & 0.044 & $0.153^{*}$ & 0.028 & $0.129^{*}$ \\
\hline & $(0.206)$ & $(0.361)$ & $(0.166)$ & $(0.337)$ \\
\hline \multirow[t]{2}{*}{ Non-agriculture before birth ${ }^{\text {a) }}$} & 0.152 & 0.092 & 0.113 & 0.069 \\
\hline & $(0.360)$ & $(0.290)$ & $(0.317)$ & $(0.254)$ \\
\hline \multirow[t]{2}{*}{ Education before birth ${ }^{\text {a) }}$} & 0.171 & $0.092 *$ & 0.190 & 0.103 \\
\hline & $(0.378)$ & $(0.290)$ & $(0.394)$ & $(0.306)$ \\
\hline \multirow[t]{2}{*}{ Inactive before birth ${ }^{a}$} & 0.608 & 0.656 & 0.648 & 0.698 \\
\hline & $(0.490)$ & $(0.477)$ & $(0.479)$ & $(0.461)$ \\
\hline Number of observations & 344 & 326 & 156 & 126 \\
\hline
\end{tabular}


Note: The sample consists of ever-married Kyrgyz women, who have given birth to at least one child, are of the age group 18-43, do not live in cities, and live below 2500 meters of altitude. Cell entries are means; standard deviation in brackets.

* indicates that the mean in the arranged marriage group is statistically different at the $5 \%$ level from the mean of the kidnapping group. ${ }^{\text {a) }}$ The number of observations is smaller for these variables than noted in the table. This is because the LIK dataset only collected information on activity status since 1989.

Source: Authors' illustration based on 2011 LIK data.

Table 4: Placebo test - OLS estimates: association between kidnapping and maternal height and chronic illness

\begin{tabular}{|c|c|c|c|c|c|}
\hline & $\begin{array}{c}\text { (1) } \\
\text { Maternal height }\end{array}$ & $\begin{array}{c}\text { (2) } \\
\text { Heart disease }\end{array}$ & $\begin{array}{c}\text { (3) } \\
\text { Lung disease }\end{array}$ & $\begin{array}{c}(4) \\
\text { Liver disease }\end{array}$ & $\begin{array}{c}(5) \\
\text { Gastrointestinal } \\
\text { disease } \\
\end{array}$ \\
\hline Kidnapped & $\begin{array}{c}0.156 \\
(0.871)\end{array}$ & $\begin{array}{c}0.005 \\
(0.006)\end{array}$ & $\begin{array}{c}0.003 \\
(0.020)\end{array}$ & $\begin{array}{l}-0.013 \\
(0.028)\end{array}$ & $\begin{array}{l}-0.006 \\
(0.006)\end{array}$ \\
\hline $\begin{array}{l}\text { Observations } \\
\text { R-squared }\end{array}$ & $\begin{array}{c}282 \\
0.328\end{array}$ & $\begin{array}{c}282 \\
0.164\end{array}$ & $\begin{array}{c}282 \\
0.125 \\
\end{array}$ & $\begin{array}{c}282 \\
0.215\end{array}$ & $\begin{array}{c}282 \\
0.339 \\
\end{array}$ \\
\hline & $\begin{array}{c}(6) \\
\text { Kidney disease }\end{array}$ & $\begin{array}{c}(7) \\
\text { High blood } \\
\text { pressure }\end{array}$ & $\begin{array}{c}(8) \\
\text { Low blood } \\
\text { pressure }\end{array}$ & $\begin{array}{c}(9) \\
\text { Spinal } \\
\text { problems }\end{array}$ & $\begin{array}{c}(10) \\
\text { Diabetes }\end{array}$ \\
\hline Kidnapped & $\begin{array}{c}0.047 * * \\
(0.022)\end{array}$ & $\begin{array}{c}0.017 \\
(0.021)\end{array}$ & $\begin{array}{c}0.006 \\
(0.004)\end{array}$ & $\begin{array}{l}-0.008 \\
(0.028)\end{array}$ & $\begin{array}{c}0.015 \\
(0.017)\end{array}$ \\
\hline $\begin{array}{l}\text { Observations } \\
\text { R-squared }\end{array}$ & $\begin{array}{c}282 \\
0.162\end{array}$ & $\begin{array}{c}282 \\
0.157\end{array}$ & $\begin{array}{c}282 \\
0.135\end{array}$ & $\begin{array}{c}282 \\
0.269\end{array}$ & $\begin{array}{c}282 \\
0186\end{array}$ \\
\hline
\end{tabular}

Note: The sample consists of ever-married Kyrgyz women, who have given birth to at least one child, are of the age group 18-43, do not live in cities, and live below 2500 meters of altitude. All estimations control for the woman's age at marriage, her educational attainment, her language proficiency, and district fixed effects. Clustered standard errors in brackets.

$* * *$ significant at $1 \%, * *$ at $5 \%, *$ at $10 \%$.

Source: Authors' illustration based on 2011 LIK data. 
Table 5: Estimates of birth weight for Kyrgyz children

\begin{tabular}{|c|c|c|c|}
\hline & $\begin{array}{c}(1) \\
\text { OLS }\end{array}$ & $\begin{array}{l}\text { (2) } \\
\text { IV }\end{array}$ & $\begin{array}{c}(3) \\
\text { OLS, with district } \\
\text { fixed effects } \\
\end{array}$ \\
\hline \multirow[t]{2}{*}{ Kidnap } & $-121.5 * * *$ & $-228.5 * * *$ & $-95.39 * *$ \\
\hline & $(46.76)$ & $(82.80)$ & $(44.71)$ \\
\hline \multirow[t]{2}{*}{ Child male } & $67.20 * *$ & $64.42 * *$ & $91.18 * * *$ \\
\hline & $(27.83)$ & $(27.44)$ & $(24.08)$ \\
\hline \multirow[t]{2}{*}{ Child firstborn } & -43.94 & -48.56 & -10.63 \\
\hline & (40.03) & $(40.10)$ & $(36.25)$ \\
\hline \multirow[t]{2}{*}{ Twin } & $-838.1 * * *$ & $-865.1 * * *$ & $-805.6^{* * *}$ \\
\hline & (255.9) & $(252.4)$ & $(221.7)$ \\
\hline \multirow[t]{2}{*}{ Age at birth } & 40.52 & 28.92 & $52.25^{*}$ \\
\hline & $(31.51)$ & $(32.12)$ & $(30.05)$ \\
\hline \multirow[t]{2}{*}{ Age at birth squared } & -0.850 & -0.658 & $-0.936^{*}$ \\
\hline & $(0.586)$ & $(0.599)$ & $(0.550)$ \\
\hline \multirow[t]{2}{*}{ Basic education } & 34.41 & 40.69 & -33.44 \\
\hline & $(108.1)$ & $(114.2)$ & (77.00) \\
\hline \multirow[t]{2}{*}{ Secondary education } & 49.81 & 22.91 & 1.391 \\
\hline & (75.68) & (79.59) & $(58.14)$ \\
\hline \multirow{2}{*}{ Technical education } & 74.69 & 93.28 & 57.06 \\
\hline & (88.03) & $(89.00)$ & (70.87) \\
\hline \multirow{2}{*}{ Kyrgyz and Russian } & -15.39 & -0.0680 & $103.2 * *$ \\
\hline & $(45.10)$ & $(45.48)$ & $(43.48)$ \\
\hline \multirow[t]{2}{*}{ Mother's height } & 4.003 & 2.904 & 4.250 \\
\hline & (4.296) & (4.513) & (2.963) \\
\hline \multirow[t]{2}{*}{ Constant } & $2,679 * * *$ & $2,475 * * *$ & $2,445 * * *$ \\
\hline & $(835.0)$ & $(888.6)$ & $(607.9)$ \\
\hline Birth month \& year FE & YES & YES & YES \\
\hline District FE & $\mathrm{NO}$ & NO & YES \\
\hline Observations & 828 & 794 & 828 \\
\hline R-squared & 0.131 & 0.127 & 0.405 \\
\hline
\end{tabular}

Note: The sample consists of ever-married Kyrgyz women, who have given birth to at least one child, are of the age group 18-43, do not live in cities, and live below 2500 meters of altitude. Clustered standard errors in brackets. $* * *$ significant at $1 \%, * *$ at $5 \%, *$ at $10 \%$.

Source: Authors' illustration based on 2011 LIK data. 
Table 6: Robustness tests

Exclude children born out of wedlock

\begin{tabular}{lccc} 
& $(1)$ OLS & (2) IV & (3) OLS, with district FE \\
\hline Kidnapped & $-135.0^{* * *}$ & $-234.6^{* * *}$ & $-112.7^{* *}$ \\
& $(47.65)$ & $(85.92)$ & $(44.63)$ \\
District FE & NO & NO & YES \\
Observations & 792 & 759 & 792 \\
R-squared & 0.129 & 0.125 & 0.410 \\
F-statistic (first stage) &. & 123.6 &. \\
\hline
\end{tabular}

Observations below 2000m of altitude

\begin{tabular}{lccc} 
& (4) OLS & (5) IV & (6) OLS, with district FE \\
\hline Kidnapped & $-111.8^{* *}$ & $-252.6^{* * *}$ & $-94.74^{* *}$ \\
& $(49.41)$ & $(94.44)$ & $(45.97)$ \\
& & & \\
District FE & NO & NO & YES \\
Observations & 748 & 714 & 748 \\
R-squared & 0.129 & 0.116 & 0.423 \\
F-statistic (first stage) &. & 107.0 &. \\
\hline
\end{tabular}

Controlling for mother's employment in the year before birth

\begin{tabular}{lccc} 
& (7) OLS & $(8)$ IV & (9) OLS, with district FE \\
\hline Kidnapped & $-122.4^{* *}$ & $-224.1^{* * *}$ & $-98.02^{* *}$ \\
& $(47.68)$ & $(94.05)$ & $(45.43)$ \\
& & & \\
District FE & NO & NO & YES \\
Observations & 791 & 757 & 791 \\
R-squared & 0.129 & 0.124 & 0.415 \\
F-statistic (first stage) &. & 123.3 &. \\
\hline
\end{tabular}

Controlling for father's educational attainment

\begin{tabular}{lccc} 
& $(10)$ OLS & $(11)$ IV & (12) OLS, with district FE \\
\hline Kidnapped & $-116.8^{* *}$ & $-211.8^{* *}$ & $-99.41^{* *}$ \\
& $(49.26)$ & $(87.10)$ & $(48.75)$ \\
& & & \\
District FE & NO & NO & YES \\
Observations & 749 & 721 & 749 \\
R-squared & 0.136 & 0.135 & 0.423 \\
F-statistic (first stage) &. & 113.0 &. \\
\hline
\end{tabular}

\begin{tabular}{lccc}
\hline & \multicolumn{3}{c}{ Only women with maximum two children } \\
& $(13)$ OLS & $(14) \mathrm{IV}$ & $(15)$ OLS, with district FE \\
\hline Kidnapped & $-182.3^{* *}$ & $-255.8^{* *}$ & $-190.6^{* *}$ \\
& $(80.05)$ & $(114.6)$ & (104.1)
\end{tabular}

$\begin{array}{llll}\text { District FE NO NO } & \text { NES }\end{array}$ 


\begin{tabular}{lccc} 
Observations & 196 & 181 & 196 \\
R-squared & 0.286 & 0.317 & 0.539 \\
F-statistic (first stage) &. & 57.8 &. \\
\hline
\end{tabular}

New definition for old generation (cutoff: marriage before 1992)

\begin{tabular}{lccc} 
& $(16)$ OLS & $(17)$ IV & (18) OLS, with district FE \\
\hline Kidnapped & $-110.7^{* *}$ & $-224.1^{* *}$ & -69.23 \\
& $(48.27)$ & $(94.05)$ & $(47.57)$ \\
District FE & & & \\
Observations & NO & NO & YES \\
R-squared & 669 & 650 & 669 \\
F-statistic (first stage) & 0.130 & 0.115 & 0.387 \\
\hline
\end{tabular}

Note: The sample consists of ever-married Kyrgyz women, who have given birth to at least one child, are of the age group 18-43 (except in columns (7)-(9)), do not live in cities, and live below 2500 meters of altitude (except in columns (4)-(6)). All estimations include the control variables as well as birth and month fixed effects as defined in equation (1). Clustered standard errors in brackets.

$* * *$ significant at $1 \%, * *$ at $5 \%$, * at $10 \%$.

Source: Authors' illustration based on 2011 LIK data. 
Table 7: OLS estimates of alternative stress outcomes

\begin{tabular}{|c|c|c|}
\hline & $\begin{array}{c}(1) \\
\text { Dependent variable: } \\
\text { Divorce } \\
\end{array}$ & $\begin{array}{c}\text { (2) } \\
\text { Dependent variable: } \\
\text { Satisfaction with family life }\end{array}$ \\
\hline \multirow[t]{2}{*}{ Kidnap } & $0.108^{*}$ & 0.205 \\
\hline & $(0.0586)$ & $(0.280)$ \\
\hline \multirow[t]{2}{*}{ Divorced } & & $-2.508 * * *$ \\
\hline & & $(0.875)$ \\
\hline \multirow[t]{2}{*}{ Kidnap*Divorced } & & $-2.558 * *$ \\
\hline & & $(1.161)$ \\
\hline \multirow[t]{2}{*}{ Age at marriage } & 0.048 & 0.009 \\
\hline & $(0.057)$ & $(0.257)$ \\
\hline \multirow[t]{2}{*}{ Age at marriage squared } & -0.001 & -0.001 \\
\hline & $(0.001)$ & $(0.005)$ \\
\hline \multirow[t]{2}{*}{ Basic education } & 0.101 & 0.619 \\
\hline & $(0.108)$ & $(1.144)$ \\
\hline \multirow[t]{2}{*}{ Secondary education } & -0.099 & -0.008 \\
\hline & $(0.108)$ & $(0.633)$ \\
\hline \multirow{2}{*}{ Technical education } & -0.117 & 0.656 \\
\hline & $(0.096)$ & $(0.652)$ \\
\hline \multirow[t]{2}{*}{ Kyrgyz and Russian } & 0.044 & 0.202 \\
\hline & $(0.045)$ & $(0.301)$ \\
\hline \multirow[t]{2}{*}{ Height } & 0.002 & 0.013 \\
\hline & $(0.002)$ & $(0.025)$ \\
\hline \multirow[t]{2}{*}{ Constant } & -0.674 & 3.040 \\
\hline & $(0.857)$ & $(5.297)$ \\
\hline District FE & YES & YES \\
\hline Observations & 282 & 273 \\
\hline R-squared & 0.237 & 0.573 \\
\hline
\end{tabular}

Note: The sample consists of ever-married Kyrgyz women in arranged or kidnapped marriages, who have given birth to at least one child, are of the age group 18-43, do not live in cities, and live below 2500 meters of altitude. Clustered standard errors in brackets.

$* * *$ significant at $1 \%, * *$ at $5 \%, *$ at $10 \%$.

Source: Authors' illustration based on 2011 LIK data. 
Table 8: Percentage of husbands and wives giving similar responses to personality questions, across marriage type

\begin{tabular}{llcc}
\hline & $\begin{array}{c}\text { Love } \\
\text { marriage } \\
(\mathrm{N}=405)\end{array}$ & $\begin{array}{c}(1) \\
\text { Arranged } \\
\text { marriage } \\
(\mathrm{N}=115)\end{array}$ & $\begin{array}{c}\text { Kidnapped } \\
\text { marriage } \\
(\mathrm{N}=120)\end{array}$ \\
I see myself as someone who ... & 74.32 & 80.00 & 75.00 \\
\hline keeps distance & 81.98 & 80.00 & 70.83 \\
tends to find fault with others & 83.46 & 86.96 & 80.00 \\
does a thorough job & 81.98 & 86.96 & 71.67 \\
is depressed & 80.99 & 82.61 & 74.17 \\
is curious about many different things & 78.52 & 87.83 & 71.67 \\
generates a lot of enthusiasm & 84.44 & 84.35 & 75.00 \\
generally trusts other people & 80.74 & 81.74 & 72.50 \\
tends to be lazy & 80.49 & 75.65 & 70.83 \\
is relaxed, handles stress well & 81.98 & 84.35 & 75.00 \\
is ingenious, a deep thinker & 71.60 & 75.65 & 75.83 \\
tends to be quiet & 76.05 & 74.78 & 70.83 \\
can be cold and aloof & 78.27 & 82.61 & 69.17 \\
is inventive & 75.06 & 73.04 & 71.67 \\
worries a lot & 79.51 & 79.13 & 68.33 \\
has an active imagination & 66.42 & 66.09 & 67.50 \\
is outgoing, sociable & 74.57 & 69.57 & 67.50 \\
is sometimes rude to others & 80.99 & 80.87 & 73.33 \\
makes plans and follows through with them & 76.05 & 80.87 & 70.00 \\
gets nervous easily & 77.28 & 83.48 & 73.33 \\
values art and esthetic events & 73.58 & 74.78 & 73.33 \\
has few artistic interests & & &
\end{tabular}

Source: Authors' illustration based on 2012 LIK data. 
Appendix 
Figure A1: Histogram of district-level share of kidnappings

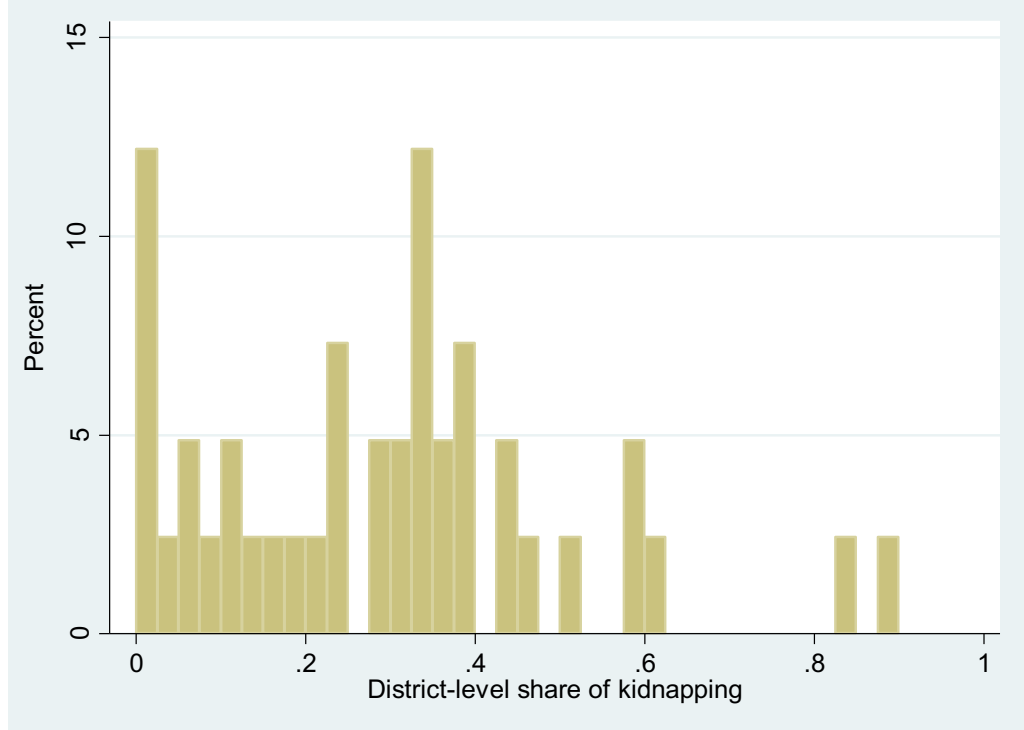

Source: Authors' illustration based on 2011 LIK data.

Figure A2: Non-Kyrgyz children in districts with different kidnapping prevalence

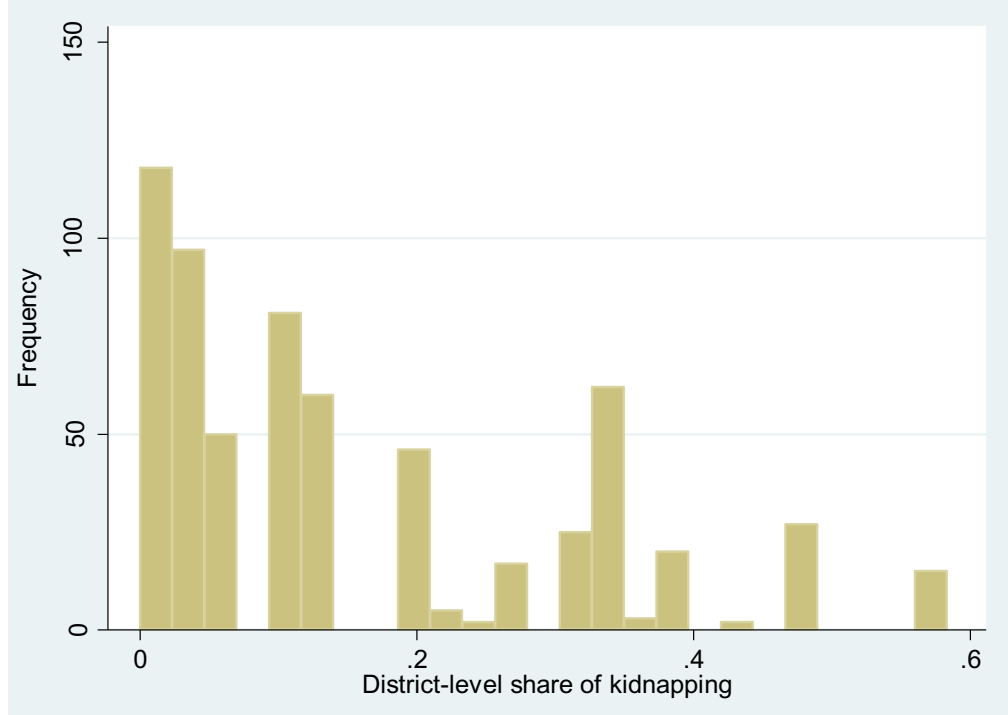

Source: Authors' illustration based on 2011 LIK data. 
Table A1: Educational attainment of husbands and wives across marriage type

\begin{tabular}{lccc}
\hline & $\begin{array}{c}(1) \\
\text { Love marriage }\end{array}$ & $\begin{array}{c}(2) \\
\text { Arranged } \\
\text { marriage }\end{array}$ & $\begin{array}{c}(3) \\
\text { Kidnapped } \\
\text { marriage }\end{array}$ \\
\hline & $(\mathrm{N}=392)$ & $\begin{array}{c}\text { Husbands } \\
(\mathrm{N}=104)\end{array}$ & $(\mathrm{N}=116)$ \\
\hline Basic education & 5.36 & 4.81 & 9.48 \\
Secondary education & 54.85 & 75.96 & 68.97 \\
Technical education & 22.60 & 13.46 & 16.38 \\
University education & 22.19 & 5.77 & 5.17 \\
& & & 51.7 \\
Proficiency of Kyrgyz and & 68.9 & 61.7 & $(\mathrm{~N}=156)$ \\
Russian & & Wives & 8.97 \\
& $(\mathrm{~N}=446)$ & 2.38 & 62.82 \\
& 4.26 & 80.16 & 19.23 \\
Basic education & 55.38 & 11.11 & 8.97 \\
Secondary education & 15.92 & 6.35 & 52.5 \\
Technical education & 24.44 & & \\
University education & & 55.6 & \\
Proficiency of Kyrgyz and & 66.7 & & \\
Russian & & & \\
\hline Source: Authors' illustration based on $2011 \mathrm{LIK}$ data & & & \\
\hline
\end{tabular}

Source: Authors' illustration based on 2011 LIK data. 
Table A2: First-stage estimate

\begin{tabular}{|c|c|}
\hline & $\begin{array}{l}\text { Dependent variable: } \\
\text { Kidnapping }\end{array}$ \\
\hline District-level share of & $1.142 * * *$ \\
\hline kidnappings & $(0.104)$ \\
\hline \multirow[t]{2}{*}{ Child male } & 0.008 \\
\hline & $(0.031)$ \\
\hline \multirow[t]{2}{*}{ Child firstborn } & -0.078 \\
\hline & $(0.040)$ \\
\hline \multirow[t]{2}{*}{ Twin } & $-0.268 *$ \\
\hline & $(0.140)$ \\
\hline \multirow[t]{2}{*}{ Age at birth } & -0.033 \\
\hline & $(0.033)$ \\
\hline \multirow[t]{2}{*}{ Age at birth squared } & 0.000 \\
\hline & $(0.001)$ \\
\hline \multirow[t]{2}{*}{ Basic education } & -0.058 \\
\hline & $(0.149)$ \\
\hline \multirow[t]{2}{*}{ Secondary education } & $-0.233 * *$ \\
\hline & $(0.105)$ \\
\hline \multirow[t]{2}{*}{ Technical education } & -0.106 \\
\hline & $(0.124)$ \\
\hline \multirow[t]{2}{*}{ Kyrgyz and Russian } & 0.064 \\
\hline & $(0.058)$ \\
\hline \multirow[t]{2}{*}{ Mother's height } & -0.004 \\
\hline & $(0.005)$ \\
\hline \multirow[t]{2}{*}{ Constant } & 1.396 \\
\hline & $(0.930)$ \\
\hline Birth month \& year FE & YES \\
\hline Observations & 794 \\
\hline R-squared & 0.378 \\
\hline Adjusted R-squared & 0.338 \\
\hline Partial R-squared & 0.276 \\
\hline F-stat of instrument & 127.5 \\
\hline
\end{tabular}

Note: The sample consists of ever-married Kyrgyz women, who have given birth to at least one child, are of the age group 18-43, do not live in cities, and live below 2500 meters of altitude. Clustered standard errors in brackets.

$* * *$ significant at $1 \%, * *$ at $5 \%, *$ at $10 \%$.

Source: Authors' illustration based on 2011 LIK data. 
Table A3: Time use (number of hours per day), by type of marriage

\begin{tabular}{lcc}
\hline & $\begin{array}{c}\text { Kidnapped } \\
\text { marriage }\end{array}$ & $\begin{array}{c}\text { Arranged } \\
\text { marriage }\end{array}$ \\
\hline Sleep & 7.87 & 7.79 \\
& $(1.49)$ & $(1.15)$ \\
Personal care and eating & 3.51 & $3.29 *$ \\
& $(0.88)$ & $(0.83)$ \\
Child care & 1.53 & 1.78 \\
& $(1.72)$ & $(1.60)$ \\
Elderly care & 0.03 & $0.16 *$ \\
& $(0.16)$ & $(0.51)$ \\
Housework & 5.82 & 5.77 \\
& $(2.80)$ & $(2.35)$ \\
Leisure & 3.25 & 3.51 \\
& $(2.57)$ & $(2.35)$ \\
Travel & 0.26 & 0.16 \\
& $(0.88)$ & $(0.44)$ \\
Education & 0.09 & 0.01 \\
& $(0.82)$ & $(0.09)$ \\
Work & 1.62 & 1.53 \\
& $(3.25)$ & $(2.82)$ \\
Table A4: Birth intervals (number of days), by type of marriage
\end{tabular}

Note: The sample consists of ever-married Kyrgyz women, who have given birth to at least one child, are of the age group 18-43, do not live in cities, and live below 2500 meters of altitude. Cell entries are mean number of days between births; standard deviation in brackets.

* indicates that the mean of arranged marriage is statistically different at the 5\% level from the mean of kidnapping. Source: Authors' illustration based on 2011 LIK data. 